\title{
Magnetic mineralogy of soils across the Russian Steppe: climatic dependence of pedogenic magnetite formation
}

\author{
B.A. Maher ${ }^{\mathrm{a}, *}$, A. Alekseev ${ }^{\mathrm{b}}$, T. Alekseeva ${ }^{\mathrm{b}}$ \\ a Centre for Environmental Magnetism and Paleomagnetism, Lancaster Environment Centre, Department of Geography, \\ Lancaster University, Lancaster LA1 4YB, UK \\ b Institute of Physicochemical and Biological Problems of Soil Science, Russian Academy of Sciences, Pushchino, Russia
}

Received 15 January 2003; received in revised form 23 July 2003; accepted 19 August 2003

\begin{abstract}
Formation of ferrimagnets in well-drained, buffered, unpolluted soils appears to be related to climate, and especially rainfall. If robust, this magnetism/rainfall couple can be used to estimate past rainfall from buried soils, particularly the multiple soils of the Quaternary loess/soil sequences of Central Asia. However, dispute exists regarding the role of climate vs. dust flux for the magnetic properties of modern loessic soils. Here, we examine the mineralogical basis of the magnetism/rainfall link for a climate transect across the loess-mantled Russian steppe, where, critically, dust accumulation is minimal at the present day. Magnetic and independent mineralogical analyses identify in situ formation of ferrimagnets in these grassland soils; increased ferrimagnetic concentrations are associated with higher annual rainfall. XRD and electron microscopy show the soil-formed ferrimagnets are ultrafinegrained $(<\sim 50 \mathrm{~nm}$ ) and pure. Ferrimagnetic contributions to Mössbauer spectra range from $17 \%$ in the parent loess to $42 \%$ for a subsoil sample from the highest rainfall area. Total iron content varies little but the systematic magnetic increases are accompanied by decreased $\mathrm{Fe}^{2+}$ content, reflecting increased silicate weathering. For this region, parent materials are loessial deposits, topography is rolling to flat and duration of soil formation effectively constant. The variations in soil magnetic properties thus predominantly reflect climate (and its co-variant, organic activity) statistical analysis identifies strongest relationships between rainfall and magnetic susceptibility and anhysteretic remanence. This magnetic response correlates with that of the modern soils across the Chinese Loess Plateau. Such correlation suggests that the rainfall component of the climate system, not dust flux, is a key influence on soil magnetic properties in both these regions.
\end{abstract}

(C) 2003 Elsevier B.V. All rights reserved.

Keywords: soil magnetism; palaeoclimate; loessic soils; Russian steppe

\section{Introduction}

The magnetic mineralogy of sediments, includ-

* Corresponding author. Fax: +44-1524-947099.

E-mail address: b.maher@lancs.ac.uk (B.A. Maher). ing soils, is an increasingly important natural source of climatic and environmental information. The pedogenic (i.e. in situ, soil-formed) magnetic properties of well-drained, buffered and unpolluted soils appear to be causally related to climate, and specifically, rainfall (Maher et al., 1994; Han et al., 1996). Evaluation of the robust- 
ness of this climate/magnetism couple is important, as it may provide a quantitative transfer function, enabling calculation of palaeoprecipitation through the Quaternary period, via analysis of the magnetic properties of palaeosols interbedded within the loess sequences of central Asia (Heller et al., 1993; Maher et al., 1994). Robust and quantitative proxies of rainfall are notably scarce within the palaeoclimate context, and are especially significant for the densely-populated regions of monsoonal Asia.

Sensitivity of certain soil iron compounds to climate has previously been documented in the mainstream soil science literature. Notably, Schwertmann and Taylor and collaborators demonstrated (mostly on the basis of bulk X-ray diffraction (XRD) analyses) the response of haematite and goethite to different, climatically-driven pedogenic regimes. For example, the goethitehaematite ratio in soils varies systematically along climatic, hydrological and topographic transects, as a result of variations in $\mathrm{pH}$, soil temperature, water activity and organic matter (Schwertmann, 1988). Conversely, the magnetic properties of soils are often dominated by formation of the strongly magnetic (ferrimagnetic) oxides, magnetite and maghemite - usually in concentrations indetectable by XRD but easily measurable by routine magnetic methods of analysis. Hence, magnetic analyses of soils provide an additional, sensitive window on soil iron and its response to climate.

Apparent coupling between magnetism of loessic soils and rainfall was first observed for modern soils developed on the near-horizontal, homogenous parent substrates of the famous Loess Plateau region of north-central China (Maher et al., 1994; Liu et al., 1995). At the present day, this region experiences a strong gradient in rainfall, from values around $300 \mathrm{~mm} \mathrm{yr}^{-1}$ in the west, to $\sim 550 \mathrm{~mm} \mathrm{yr}^{-1}$ in the central Plateau and $\sim 700$ $\mathrm{mm} \mathrm{yr}^{-1}$ in the south. Most rainfall occurs in the summer, due to monsoonal transport of warm, moisture-laden air from the Pacific across the Chinese mainland. The extent of westward penetration of the monsoonal rainbelt varies with the intensity of the summer monsoon system. Maher et al. (1994) examined the relationships between pedogenic magnetic susceptibility and modern cli- mate variables. The magnetic susceptibility (the 'magnetisability') of the Chinese soils is dominantly contributed by trace amounts $(\sim 0.3 \%)$ of magnetite of ultrafine grain size $(<\sim 30 \mathrm{~nm})$. (Because of its fine grain size, this magnetite is variably oxidised at its surface towards maghemite). To isolate the in situ, soil-formed magnetic signal, the pedogenic susceptibility $\left(\chi_{\text {ped }}\right)$ was defined for each soil as the maximum susceptibility value $(\chi)$ of the $\mathrm{B}$ horizon minus the $\chi$ of the parent loess. Maher et al. (1994) found strong positive correlation $\left(\mathrm{R}^{2}=0.94\right)$ between the logarithm of pedogenic $\chi$ and annual rainfall. Similarly, Han et al. (1996) examined a further 63 topsoil samples across the Loess Plateau and also identified a direct (albeit polynomial) relationship between rainfall and susceptibility.

Fig. 1 summarises the magnetic and rainfall data for modern soils across the Chinese region, and also published magnetic data for soils across the Northern Hemisphere temperate zone. Some of the scatter in the data may reflect inclusion of 'unsuitable' soils, i.e. soils with conditions inimical to pedogenic formation of ferrimagnets. These include: poorly-drained or excessively acidic soils, eroded soils, or soils developing on slowly-weathering or iron-deficient substrates. Polluted soils and burnt soils, on the other hand, may be excessively enriched in ferrimagnets (Maher, 1986; Maher and Thompson, 1999). However, another possibility is that the scatter is real and that the magnetism/rainfall relationship is less significant than has been proposed. Kukla and co-workers (Kukla et al., 1988; Porter et al., 2001) have proposed that the variations in magnetic susceptibility across and within the Chinese loess sequences are due to differing rates of input of low-susceptibility dust. Indeed, Porter et al. (2001) suggest that $84 \%$ of the susceptibility variance of the modern soils across the Loess Plateau is due to the so-called 'dust-dilution' effect. For the Chinese Loess Plateau, the confounding factor in pinpointing the respective roles of climate and dust flux is that these two factors co-vary across the region. That is, annual rainfall increases and dust flux decreases from the western to the southern and eastern areas of the Plateau. Hence, the 'dust' school of thought interprets the higher 


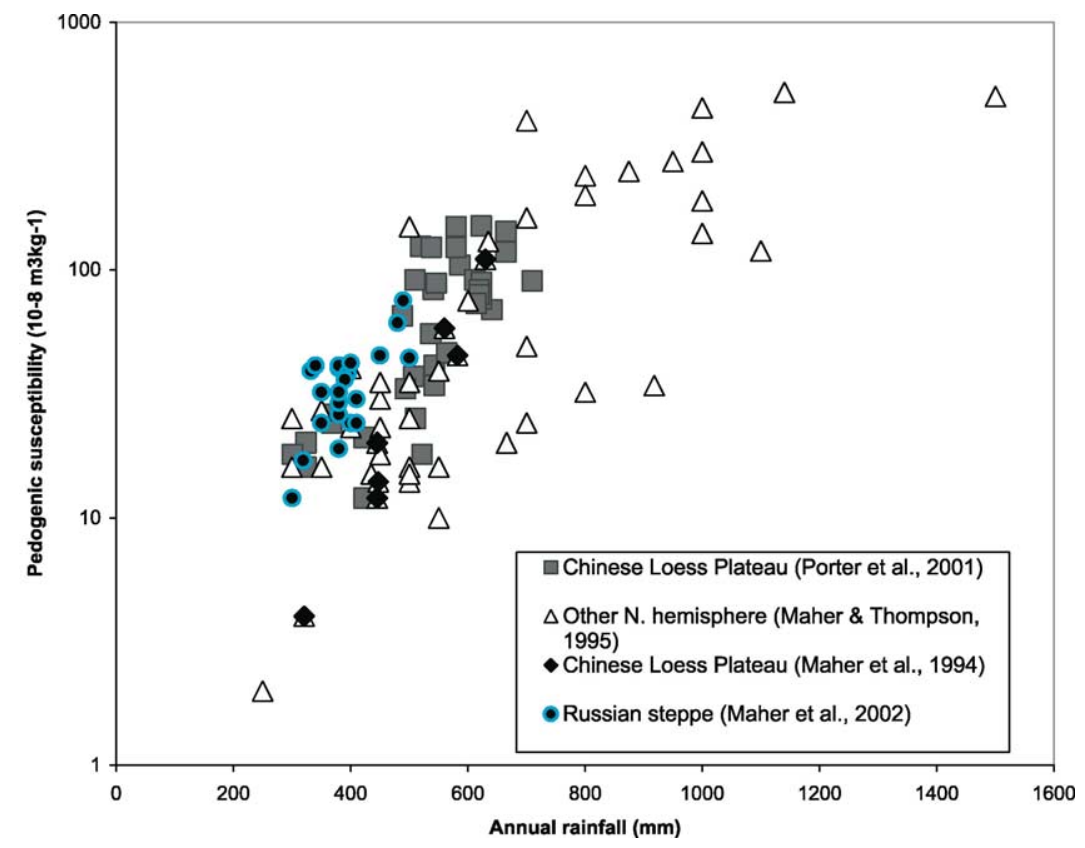

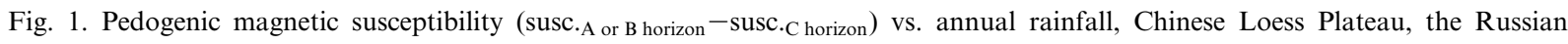
steppe and additional sites in the Northern Hemisphere temperate zone (Maher and Thompson, 1999). At high rainfall totals (i.e. beyond the range shown on this graph), soils may become decalcified, poorly buffered and pedogenic magnetite may not form and/or may be actively dissolved (Maher, 1998). Hence the rainfall/susceptibility climofunction will break down at this point.

soil magnetic values in the south and east of the Plateau as dominantly reflecting reduced input of low-susceptibility dust.

Given the scarcity of quantitative rainfall proxies available to researchers for palaeoclimatic reconstruction, it is critical to test these opposing hypotheses - climate dependence vs. dust flux dependence. The soil magnetism/climate relationship was tested recently in a geographically independent, pollution-free and geomorphologically stable region, the Russian steppe (Maher et al., 2002). In contrast to the Chinese Loess Plateau region, minimal dust accumulation occurs across this region at the present day. Here, we examine in detail the mineralogical basis of the soil magnetism/climate link observed in this region, by analysing the magnetic and mineralogical properties of 22 modern steppe soils, from a transect spanning $>1000 \mathrm{~km}$ across the loessic plain from the northern Caucasus to the Caspian Sea. Climate data for the region are available for the last $\sim 100$ years, from stations across the area. This work follows in the pioneering footsteps not only of Dokuchaev, who first identified regional scale soil/climate links (Dokuchaev, 1883), but also other Russian soil scientists, including Babanin (1973), Vadyunina and Smirnov (1976) and Vodyunitsky (1981), the first to make large-scale field and laboratory analyses of soil magnetic properties.

\section{Sites and methods}

The sampled transect exceeds $\sim 1000 \mathrm{~km}$, southwest to northeast across the loess-mantled, exhumed marine plain from the northern flanks of the Caucasus, where glacial moraine is onlapped by the loess, to the northwestern margins of the Caspian Sea (Fig. 2). The northeastern sector of the transect grades into calcareous clay loams, on marine deposits of late Pliocene/Pleistocene age. This geomorphologically stable, near-horizontal loessic and marine plain is contiguous to the west with the eastern European loess belt. The steppe in this region is notably free of any distur- 


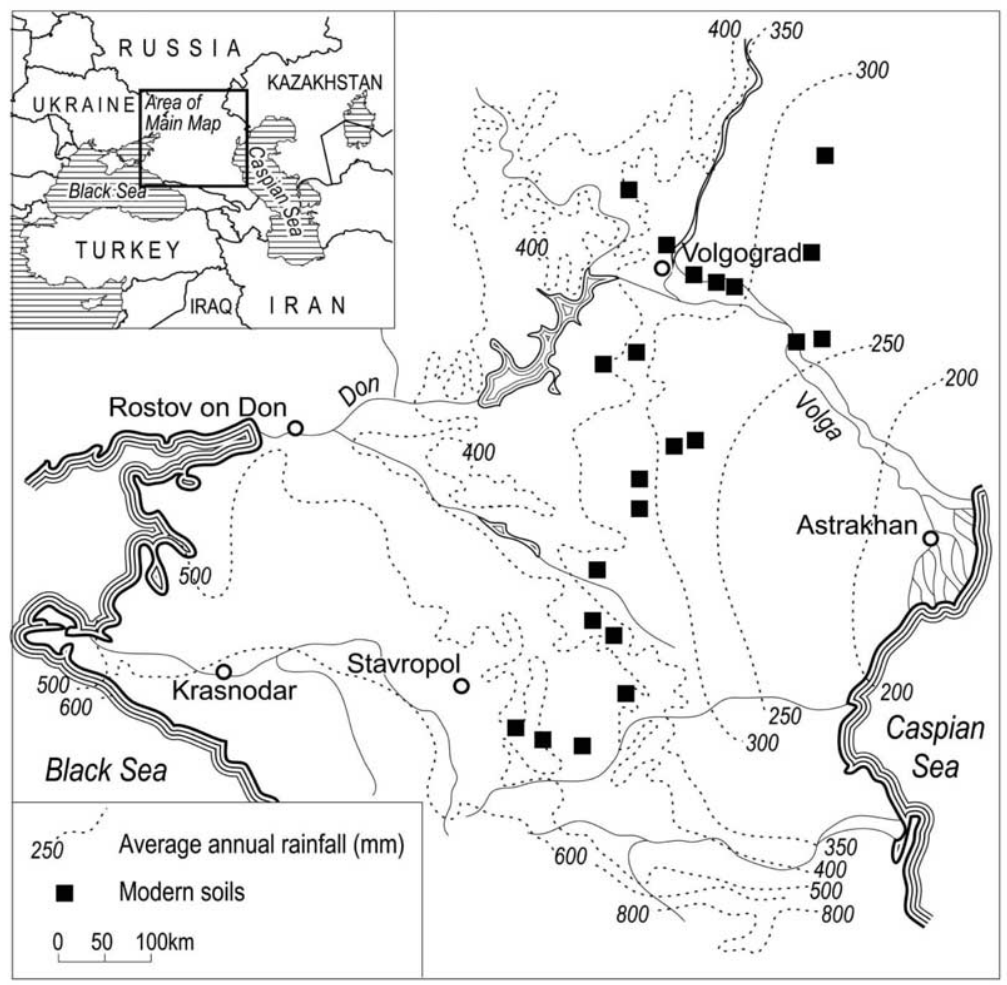

Fig. 2. Location map with sample sites, surficial geology and climate data for the sampled region (from Maher et al., 2002).

bance to the continuous grassland cover; it is extremely sparsely populated and no pollution sources exist for the sample sites. As shown in Fig. 2, the climate of the region exhibits a marked gradient in precipitation, from $\sim 500 \mathrm{~mm} / \mathrm{yr}$ for the Stavropol region to $\sim 300 \mathrm{~mm} / \mathrm{yr}$ around Volgograd. Precipitation is fairly evenly distributed throughout the year. Summer temperatures reach $\sim 25^{\circ} \mathrm{C}$, winter temperatures vary from $\sim-5$ to $-10^{\circ} \mathrm{C}$, with temperatures exceeding $10^{\circ} \mathrm{C}$ on $>\sim 170$ days/yr (State Meteorological Organisation, 1966, 1968). Fig. 2 shows the locations of the 22 transect sample points. Most of the soils are light or dark variants of Kastanozem profiles (FAO/UNESCO classification), i.e. well-drained soils with brown, humic topsoils (i.e. Ah horizons, with more than $50 \%$ of roots concentrated in the upper $25 \mathrm{~cm}$ of the soil) overlying a brown to cinnamon, argic (clay-enriched) or cambic (slightly weathered) subsoil or B horizon, and often with carbonate and/or gypsum accumula- tion in or below the B horizon (Table 1). The soils are well buffered, with $\mathrm{pH}$ values ranging from 7.2 to 8.2. Analysis of their clay mineralogy shows that smectites dominate in the soils in the northeast, whilst mica predominates elsewhere across the sampled region.

Soil augers were used to drill soil cores to $2 \mathrm{~m}$ depth, and volume magnetic susceptibility was measured for each core. Highest susceptibility values were observed for the top $40 \mathrm{~cm}$ and lowest values for the parent substrates. Soil samples were transported to the laboratory in sealed polythene bags, where subsamples were taken at $10-\mathrm{cm}$ intervals from the top $40 \mathrm{~cm}$ of each profile, together with a sample of parent material (typically 150 $180 \mathrm{~cm}$ depth). After drying at $40^{\circ} \mathrm{C}$, they were gently disaggregated and packed into 10 -cc polystyrene sample holders. The following magnetic measurements were made on each sample, using the methods outlined by Maher et al. (1999): lowand high-frequency magnetic susceptibility, an- 


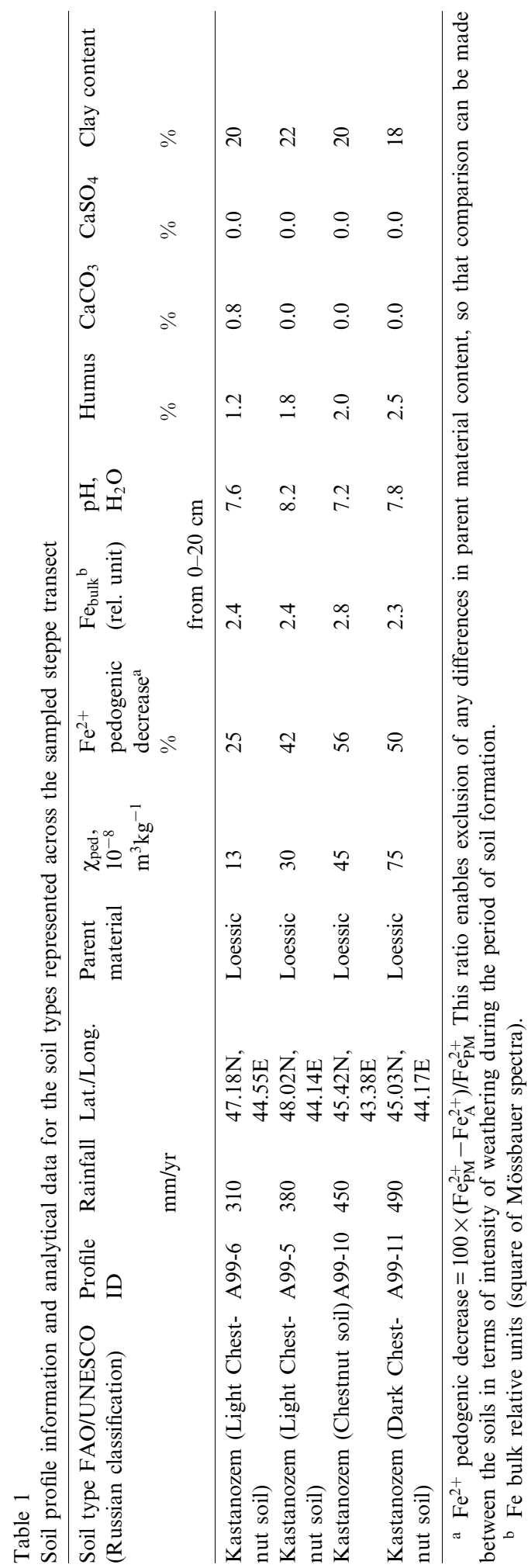

hysteretic remanence and incremental remanence acquisition and AF demagnetisation. For selected representative samples, additional hysteresis parameters were obtained using a vibrating sample magnetometer, and magnetic extraction procedures (Hounslow and Maher, 1996) were used to concentrate the magnetic carriers for independent investigation by XRD and microscopy (optical and transmission electron microscopy). Beforeand after-extraction magnetic measurements were made so that the extraction efficiency could be assessed. Finally, Mössbauer analysis was applied to representative bulk and magnetic extract samples.

The instrumentation and experimental procedures are detailed in Appendix A.

\section{Results}

\subsection{Magnetic measurements}

Magnetic susceptibility, $\chi_{\text {ARM }}$ and IRM data have been outlined elsewhere (Maher et al., 2002). Briefly, all the soils display higher magnetic susceptibility values in their A and B horizons than their C horizons (Fig. 3). Susceptibility values range from consistent minima of $\sim 5$ $20 \times 10^{-8} \mathrm{~m}^{3} \mathrm{~kg}^{-1}$ for the $\mathrm{C}$ horizon samples (the lower values associated with the marine deposits to the northeast), to a maximum of $\sim 95 \times 10^{-8}$ $\mathrm{m}^{3} \mathrm{~kg}^{-1}$ within the A horizon of Profile A99-11. Susceptibility maxima for each profile occur within the upper $30 \mathrm{~cm}$ of the individual soil profiles. Similarly, values of frequency-dependent susceptibility (normalised to the low-frequency value) range mostly between 0 and $4 \%$ in the parent substrates but from 5 to $12 \%$ in the A and B horizon samples (Fig. 4). High percentages $(>6 \%)$ of frequency-dependent susceptibility (measured at 0.47 and $4.7 \mathrm{kHz}$ ) reflect the presence of significant numbers of superparamagnetic (SP) ferrimagnetic grains, with grain diameters $<\sim 20 \mathrm{~nm}$ (e.g. Bean and Livingston, 1959; Dunlop, 1981; Maher, 1988; Dearing et al., 1996). Fig. 4 also shows the variation in anhysteretic remanence (ARM, divided by the DC field applied to become an anhysteretic susceptibility, $\chi_{\mathrm{ARM}}$ ), normalised 


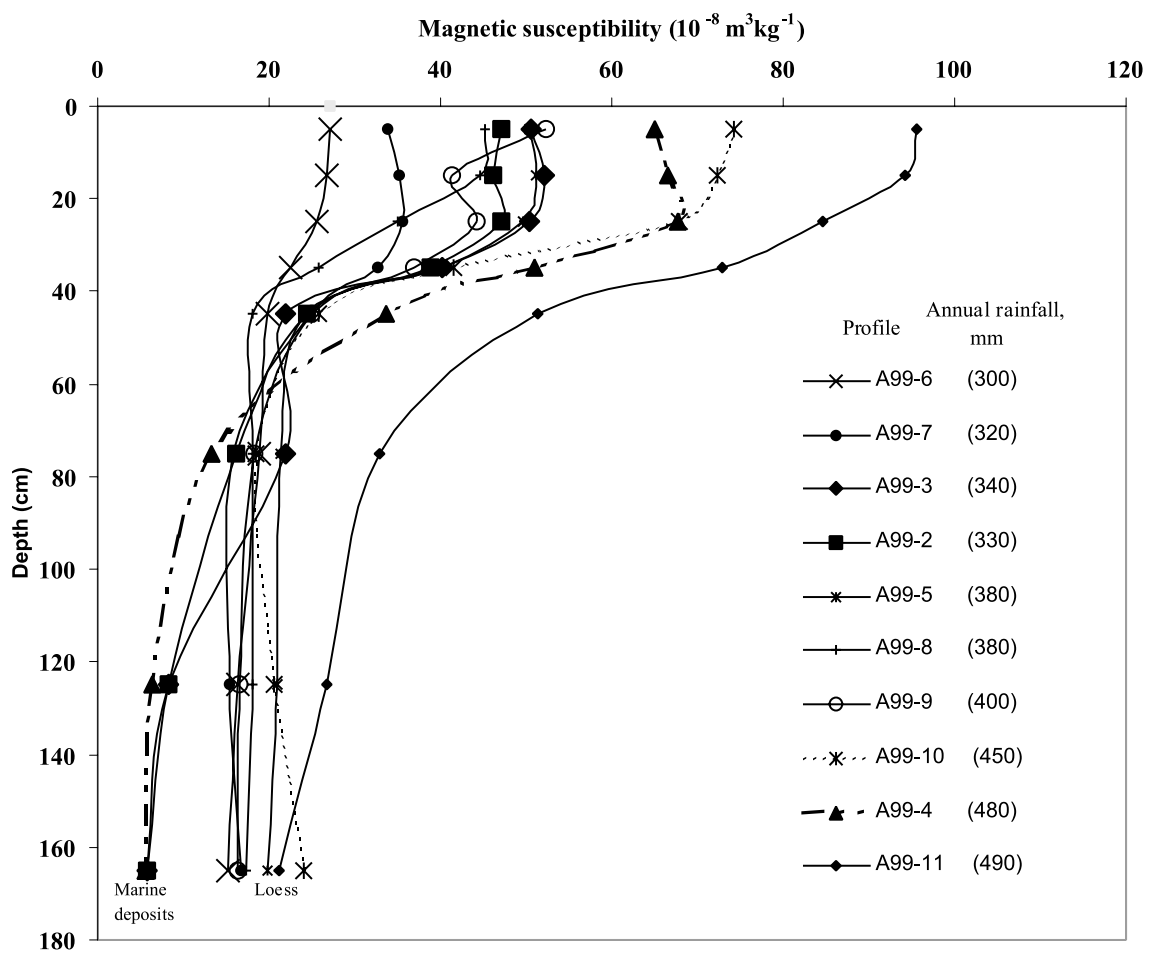

Fig. 3. Magnetic susceptibility with soil depth for representative soil profiles, A99-n, across the sampled transect, with annual rainfall $(\mathrm{mm})$ given in brackets (from Maher et al., 2002).

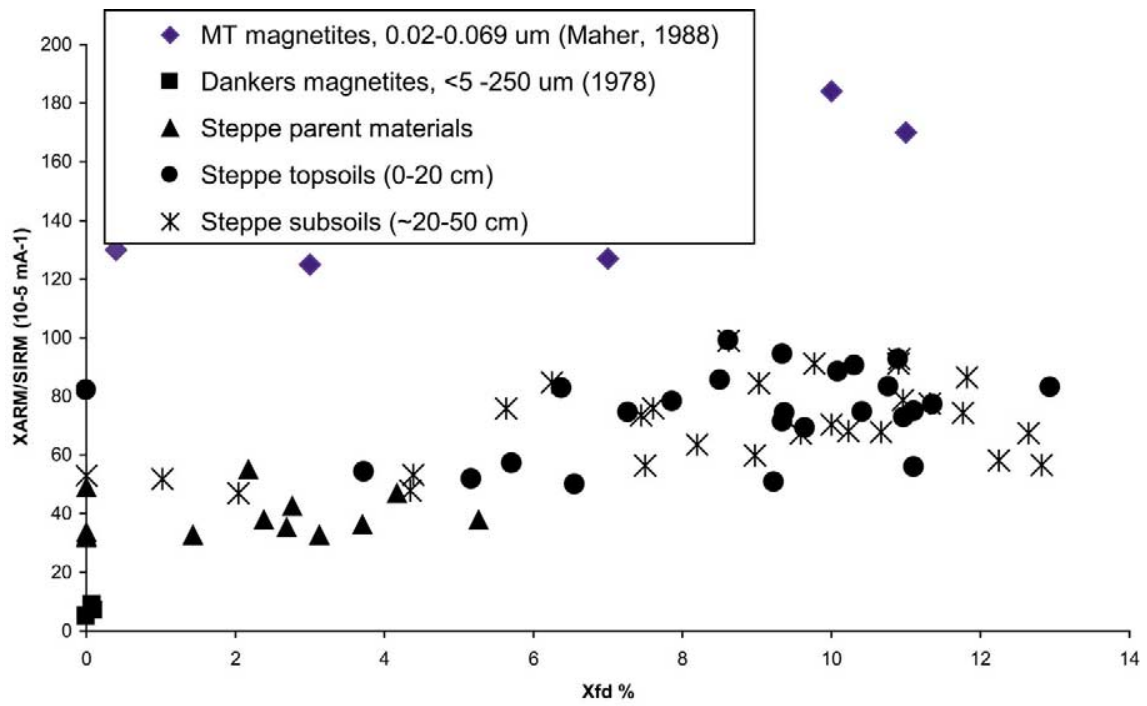

Fig. 4. $\chi_{\mathrm{ARM}}$ (normalised with respect to the SIRM) vs. $\chi_{\mathrm{fd}}$ (as a $\%$ of low frequency $\chi$ ), for sized pure magnetite powders and for $\mathrm{A}, \mathrm{B}$ and $\mathrm{C}$ horizons of the Russian steppe soils. 


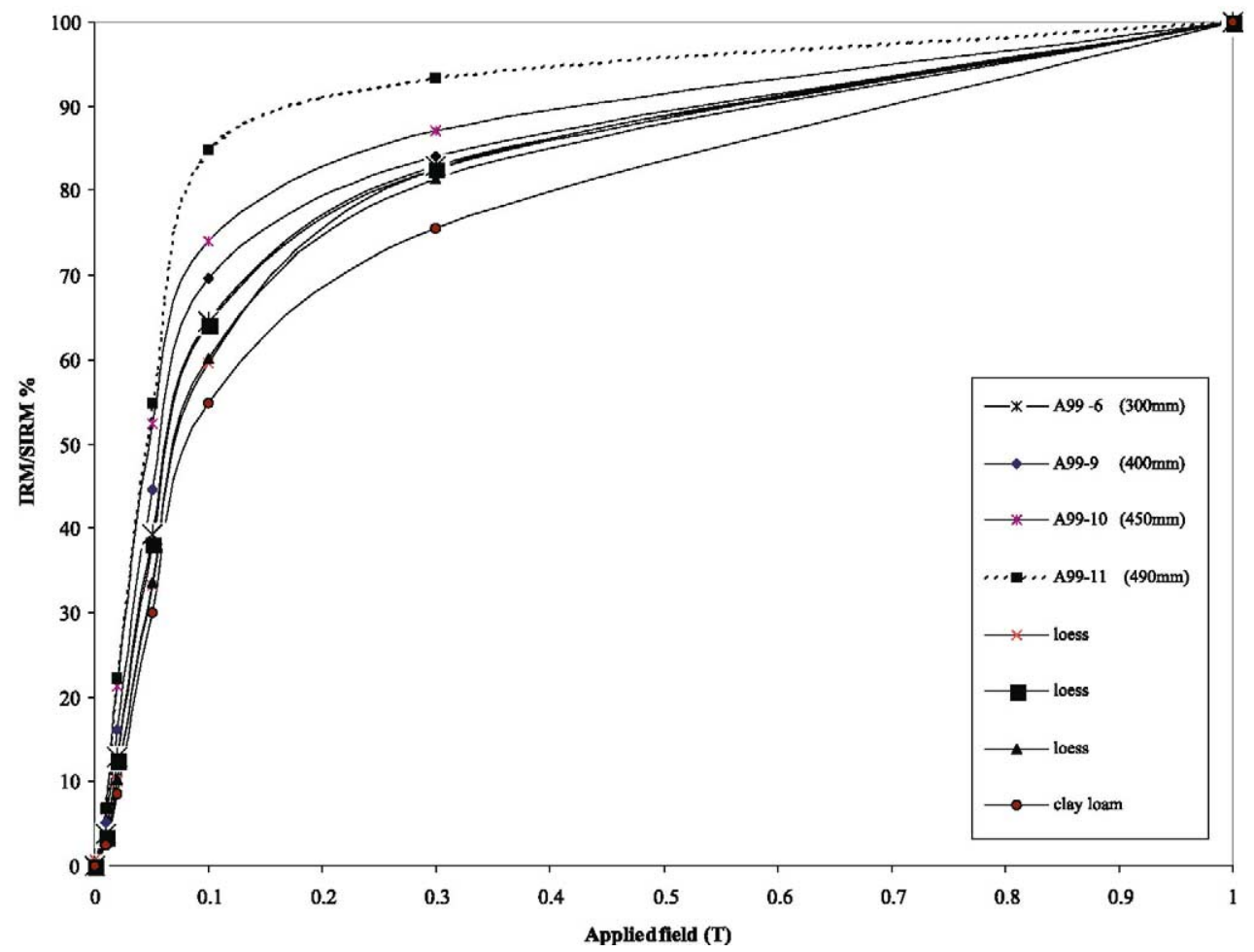

Fig. 5. IRM acquisition for representative parent material and upper (A and B) soil horizons (annual rainfall in brackets).

to the SIRM attained after application of a 1 Tesla field. The parent substrates display a narrow range of low $\chi_{\text {ARM }} /$ SIRM values (Fig. 4), while the $\mathrm{B}$ and $\mathrm{A}$ horizon samples are characterised by higher and more variable values. $\chi_{\text {ARM }}$ has been shown to be a sensitive indicator of magnetic grain size and magnetic interactions in natural samples. Highly interacting, single domain $(\sim 30-50 \mathrm{~nm})$ ferrimagnets, such as the magnetic chains made by magnetotactic bacteria, give rise to high $\chi_{\text {ARM }}$ values. Equally fine-grained but non-concatenated grains found in magneticallyenhanced soils (Özdemir and Banerjee, 1982; Maher, 1988; Maher et al., 1999) produce moderate $\chi_{\mathrm{ARM}} \mathrm{s}$, while larger, multidomain magnetic grains give rise to low $\chi_{\text {ARM }}$ values (Fig. 4; Dankers, 1978). The offset in $\chi_{\text {ARM }}$ values between the sub-micrometre synthetic magnetites and the soil samples most likely reflects the presence in the soils of haematite, which carries only a very low $\chi_{\text {ARM }}$.

'Saturation' IRM $\left(\mathrm{SIRM}_{1 \mathrm{~T}}\right)$ values for the par- ent material samples vary little, around $2.2 \times 10^{-3}$ $\mathrm{Am}^{2} \mathrm{~kg}^{-1}$ and their patterns of remanence acquisition are similar (Fig. 5). Most remanence is acquired at fields of $10-100 \mathrm{mT}(\sim 50 \%)$ but there is also significant remanence acquisition $(\sim 40 \%)$ at higher fields (300-1000 mT). The A and B horizon samples acquire slightly more low-field remanence (up to $10 \%$ at fields less than $10 \mathrm{mT}$ ) and also more remanence at fields up to $100 \mathrm{mT}$ $(\sim 70 \%)$. Their SIRM values are $2-3 \times$ higher than those of their parent samples. The magnetic hardness of the high field IRM (HIRM, i.e. acquired beyond $100 \mathrm{mT}$ ) was also examined, by first applying a $1 \mathrm{~T}$ field to representative samples, to produce an SIRM, which was then af demagnetised in a field of $100 \mathrm{mT}$. The remanence remaining following this demagnetisation (the $\mathrm{HIRM}_{100 \mathrm{mT} \text { af }}$ ) reflects the concentration of demonstrably stable, high-coercivity haematite (rather than goethite, which acquires most remanence at fields greater than the $1 \mathrm{~T}$ applied here). The HIRM values for the parent materials are 


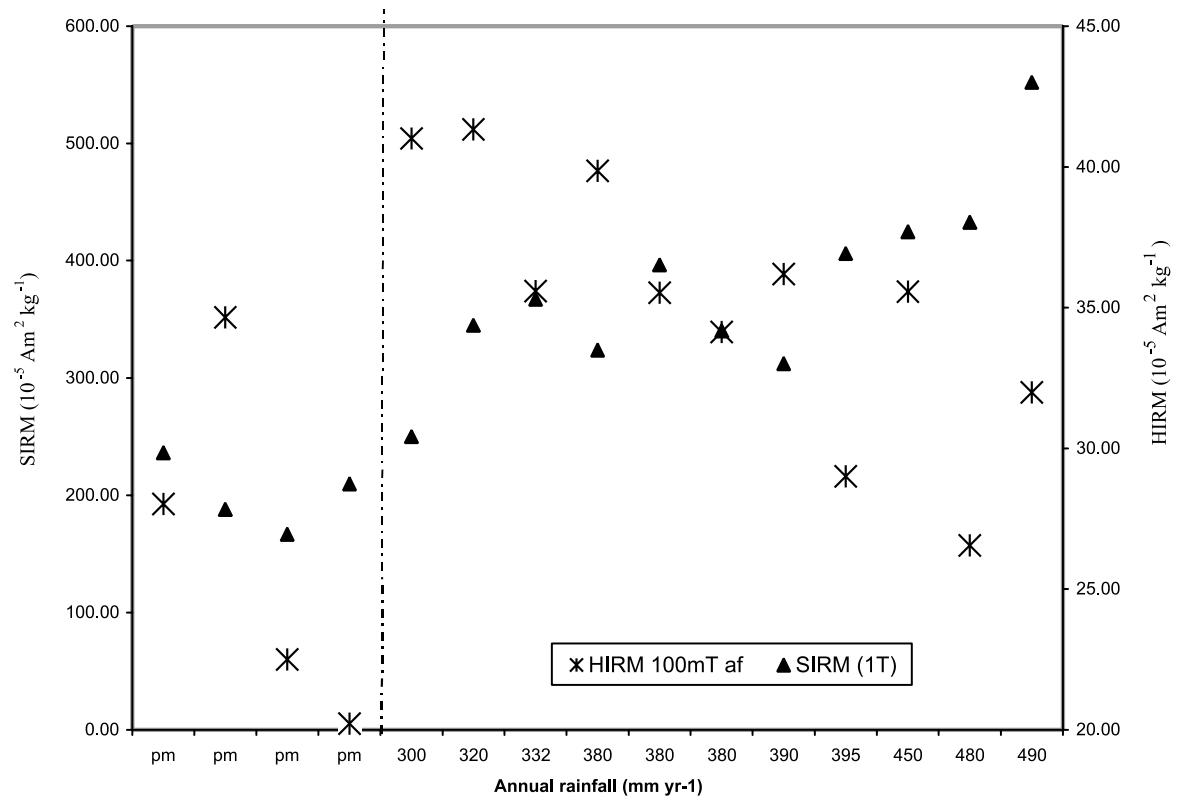

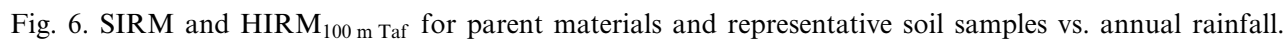

generally lower than those of the soil samples, with the exception of those soils formed in the highest rainfall areas (Fig. 6). This suggests that soil formation in the less humid areas results in the formation of haematite as well as low concentrations of ferrimagnetic minerals. However, as seen in Fig. 6, there is an indirect relationship between annual rainfall and HIRM $\mathrm{M}_{100 \mathrm{mT} \text { af }}$, the amount of haematite diminishing with increased rainfall. Finally, for the bulk samples, hysteresis loops were measured for a number of representative samples. Fig. 7 shows data for the parent material and $A_{1}$ samples from profile A99-10. In comparison with their parent substrate, the topsoil samples display steeper, thinner loops. Their ferrimagnetic contributions to susceptibility range from 85 to $95 \%$, compared to $70-79 \%$ in the parent loess; paramagnetic contributions to magnetic susceptibility are $5-15 \%$ in the soils and $21-$ $30 \%$ in the parent substrates. The topsoils also display lower coercive force values. Modelling of the remanence components using the 'Hystear' program of von Dobeneck (1996) indicates their magnetic assemblage is significantly softer overall (Fig. 7).

\subsection{Mineralogical analysis of magnetic extracts}

To obtain independent mineralogical data on the magnetic carriers in the parent substrates and the magnetically-enriched A and B horizons, magnetic extractions were performed on samples from six representative profiles spanning the climate transect. Prior to magnetic extraction, carbonate was dissolved from the samples to ensure effective sample dispersion and extraction. The magnetic properties of the treated samples were measured to check the carbonate leach had not altered them significantly. The samples were then sieved into $>38$ - and $<38-\mu \mathrm{m}$ size fractions. As shown in Fig. 8, all of the samples display much higher values of $\chi$ and ARM in their $<38-\mu \mathrm{m}$ fractions than their $>38-\mu \mathrm{m}$ fractions. This magnetic differentiation between fractions appears increasingly marked for the more magnetic soils, located in areas with higher annual rainfall values.

A magnetic probe (MP) procedure, which exposes the circulating sample slurry to a relatively low but high-gradient magnetic field, was applied to the $<38-\mu \mathrm{m}$ fractions, to extract the fine mag- 

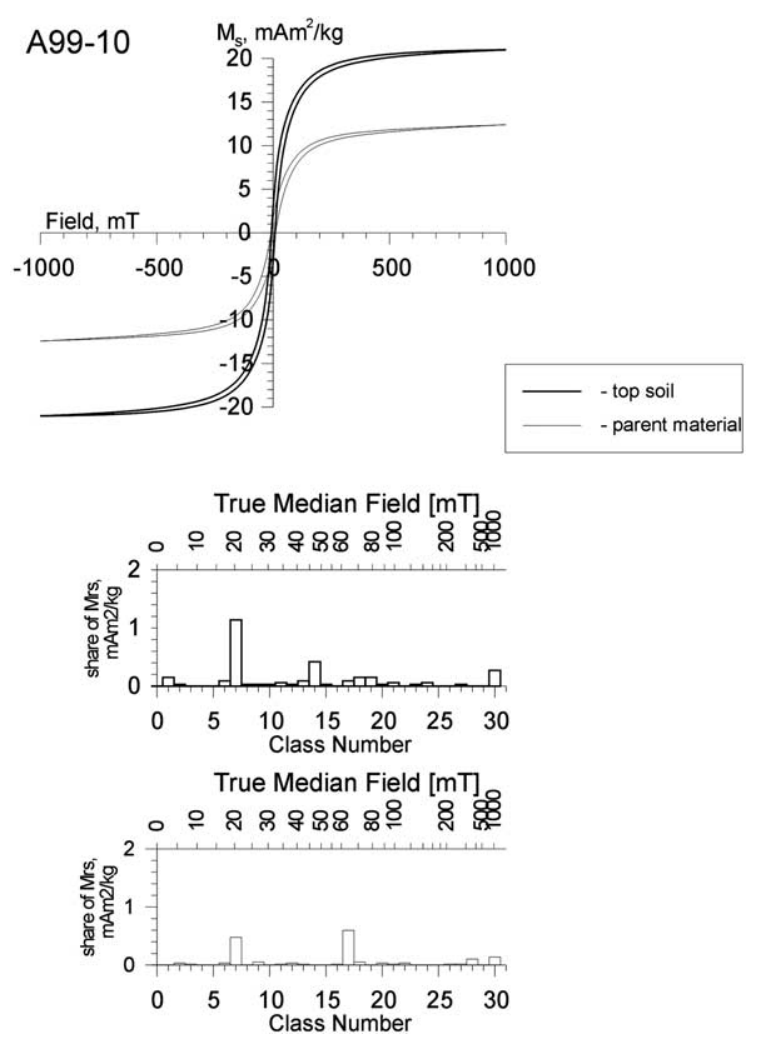

Fig. 7. Hysteresis loops for the A horizon and parent material, profile A99, together with their modeled distribution of remanence components, derived from von Dobeneck's (1996) 'Hystear' program.

netic grains. Subsequently, a magnetic edge (ME) procedure was applied to the $>38-\mu \mathrm{m}$ fraction, to concentrate the larger magnetic carriers. Both sets of methods follow those described by von Dobeneck (1985) and Hounslow and Maher (1996, 1999). To assess the effectiveness of the extractions, measurements of $\chi$ and ARM were made before and after the procedures. The extraction efficiencies for $\chi$ are $18-58 \%$, with an average of $\sim 40 \%$; for ARM, $\sim 20-70 \%$ of the signal was removed (Table 2). The variable extraction efficiency for the susceptibility carriers matches that reported by Maher (1998) for a range of modern soils. For the A and B horizon samples, the finestgrained (SP) ferrimagnets appear difficult to remove even by the MP procedure (indeed, they may even be concentrated in the non-extracted residue due, probably, to stable aggregation and association with clay minerals). For the weakly magnetic $\mathrm{C}$ horizons, more of the susceptibility is carried by paramagnets, such as clay minerals, which are also inefficiently extracted by the lowfield, high-gradient MP method.

For the $\mathrm{C}$ horizon samples, the MP procedure provided sufficient extract for analysis by XRD. Their extract mineralogy comprises haematite, with trace quantities of magnetite/maghemite, and abundant quartz, clay minerals (Alekseev et al., in press) and feldspars (Fig. 9). Silicate minerals appear in the magnetic extracts due to their paramagnetic nature, and/or the presence within them of magnetic inclusions (Hounslow and Maher, 1996; Fig. 10), and/or because of the strong association between clay minerals and the magnetic iron oxides. Examination of the MP extracts from the parent materials by transmission electron microscopy (TEM) reveals the presence of three distinct components (Fig. 11): lath-like particles (probably goethite), larger geometric Fe-rich particles, with occasional substitution with $\mathrm{Ti}$ and $\mathrm{Cr}$, of $>\sim 1 \mu \mathrm{m}$ diameter (detrital magnetite), and, rarely, some ultrafine Fe-rich particles $(<100 \mathrm{~nm})$. Analysis of the sparse ME extracts from the parent materials, by optical microscopy, identifies the presence of opaque detrital grains of haematite, and magnetite and ilmenite with oxidised, haematitic rims (martite). Additional mineral components include quartz, pyroxenes, hornblende, rutile and biotite (Fig. 9).

The XRD spectra for the MP extracts from the B horizon samples display some differences from those for the parent $\mathrm{C}$ horizon samples (Fig. 9). The magnetite/maghemite peaks are relatively broadened in the B horizons, indicating poorer crystallinity. The difference in crystallinity of the topsoil and $\mathrm{C}$ horizon ferrimagnets can be accounted for from the microscopy observations. Microscopy of the parent material extracts identifies the presence of relatively large $(0.5-2 \mu \mathrm{m})$, geometric Fe-rich particles, with common substitution by $\mathrm{Ti}$ and $\mathrm{Cr}$, of inherited (detrital) origin. TEM examination of the topsoil magnetic extracts (Fig. 11) reveals the presence of: goethitelike laths ( $\sim 500 \mathrm{~nm}$ in length), larger, geometric Fe-rich particles $(\sim 200-500 \mathrm{~nm}$ diameter $)$, and, 

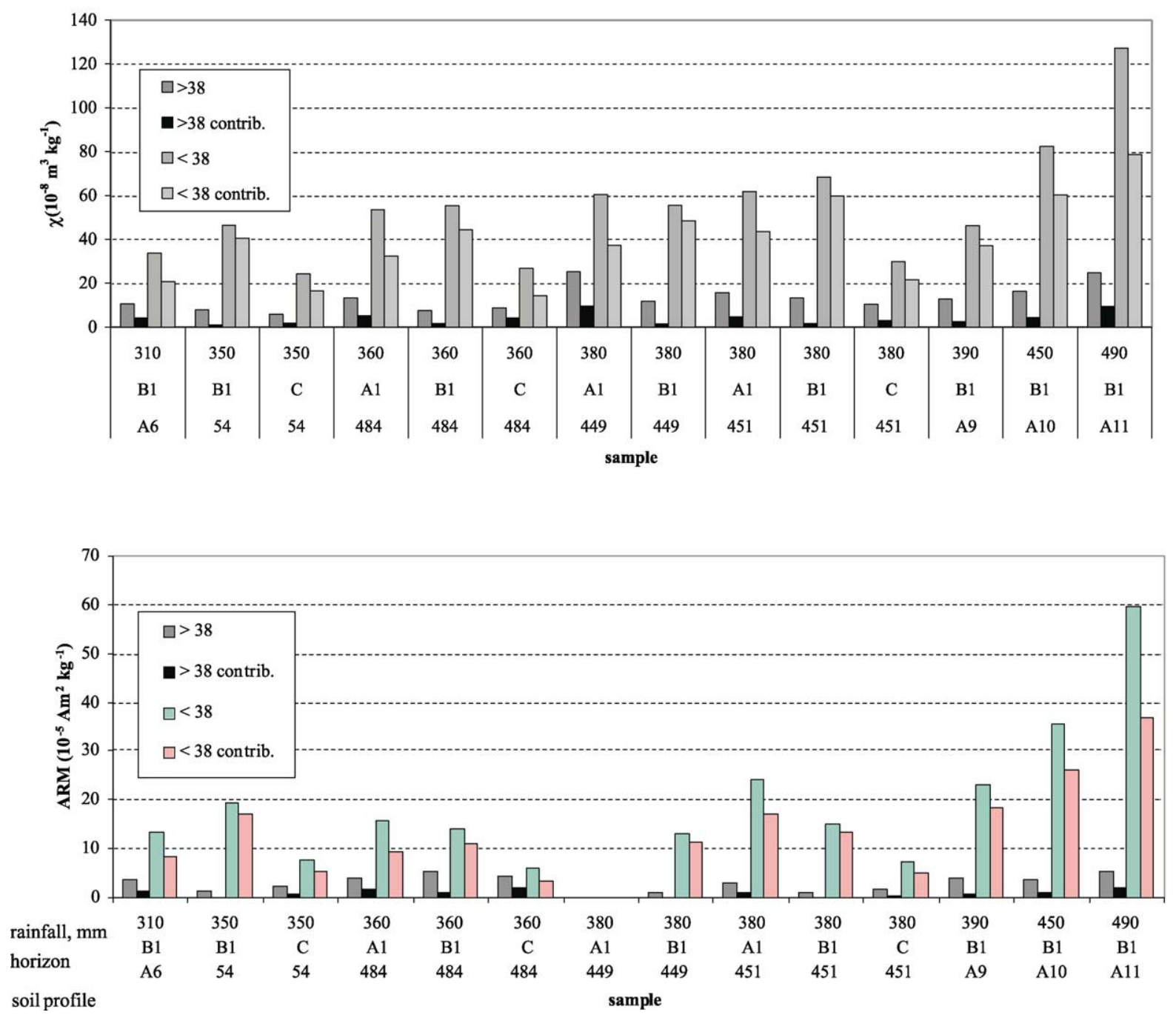

Fig. 8. The $\%$ of the $<38-$ and $>38-\mu \mathrm{m}$ particle size fractions for a range of representative $\mathrm{A}, \mathrm{B}$ and $\mathrm{C}$ horizon samples across the sampled transect, and the contribution of each fraction to the measured magnetic susceptibility (upper diagram) and $\chi_{\text {ARM }}$ (lower diagram). Annual rainfall (mm/yr) also given for each sample site.

additionally, an abundance of ultrafine-grained, geometric Fe-rich particles $(\sim 10-50 \mathrm{~nm})$ with occasional substitution with $\mathrm{Mn}$. Whereas large numbers of the ultrafine grains appear as tight clusters of particles, some are assembled in chains, resembling the chains of ferrimagnets produced by magnetotactic bacteria (Fig. 11C). None, however, display the unique, elongate 'bullet'- or 'boot'-shaped crystals that unequivocally define an intracellular, biogenic origin for such grains (e.g. Petersen et al., 1986; Vali et al., 1987) and the concatenation is likely to have occurred postdispersion and -extraction.

Thus, XRD shows that B horizon samples from these steppe soils have an additional, poorly crystalline magnetite/maghemite component compared with their parent substrates. From electron microscopy, much of this additional, strongly magnetic material appears to be ultrafine-grained $(<\sim 50 \mathrm{~nm})$ and either free from foreign cation substitution or with occasional substitution with Mn. 
Table 2

Magnetic and Mössbauer data for magnetic extracts from B horizons across the climate gradient and for a parent material sample

\begin{tabular}{|c|c|c|c|c|c|c|}
\hline Sample ID & $\begin{array}{l}\text { Annual rainfall } \\
(\mathrm{mm})\end{array}$ & $\chi 10^{-8} \mathrm{~m}^{3} \mathrm{~kg}^{-1}$ & $\chi_{\text {ARM }} 10^{-5} \mathrm{~m}^{3} \mathrm{~kg}^{1}$ & Sample mass & $\begin{array}{l}\text { Haematite, } \\
\mathrm{B}_{\mathrm{hf}}=51.9 \mathrm{~T} \\
\text { (spectr.\%) }\end{array}$ & $\begin{array}{l}\text { Magnetite+Maghemite, } \\
\mathrm{B}_{\mathrm{hf}}=45.8 / 48.8 \mathrm{~T}, \\
\mathrm{~B}_{\mathrm{hf}}=50.5 \mathrm{~T} \\
\text { (spectr.\%) }\end{array}$ \\
\hline A99-11 B & 490 & $96(31)$ & $612(48)$ & 37 & 21 & 42 \\
\hline A99-10 $B_{1}$ & 450 & $71(49)$ & $423(53)$ & 47 & 26 & 40 \\
\hline $451 \mathrm{~B}_{1}$ & 380 & $62(38)$ & $228(36)$ & 45 & 36 & 28 \\
\hline A99-6 $B_{1}$ & 310 & $27(47)$ & $152(52)$ & 18 & 38 & 29 \\
\hline Parent material $451 \mathrm{C}$ & & $22(45)$ & $102(62)$ & 25 & 40 & 17 \\
\hline
\end{tabular}

\subsection{Mössbauer analysis}

Mössbauer analysis was applied to the MP magnetic extracts from the $\mathrm{B}$ horizons of four soils spanning the climate gradient, and from a parent material sample (Table 2). The sampled transect displays little variation in terms of total iron content, with (relative) values from 2.3 to 2.8
(Table 1). However, room temperature spectra (Fig. 12) display increasing contributions by magnetite and maghemite in the topsoils from areas with higher rainfall values. Ferrimagnetic contributions to the observed spectra range from a minimum of $17 \%$ for a parent material sample to a maximum of $42 \%$ for the B horizon sample from the area with the highest annual rainfall (profile

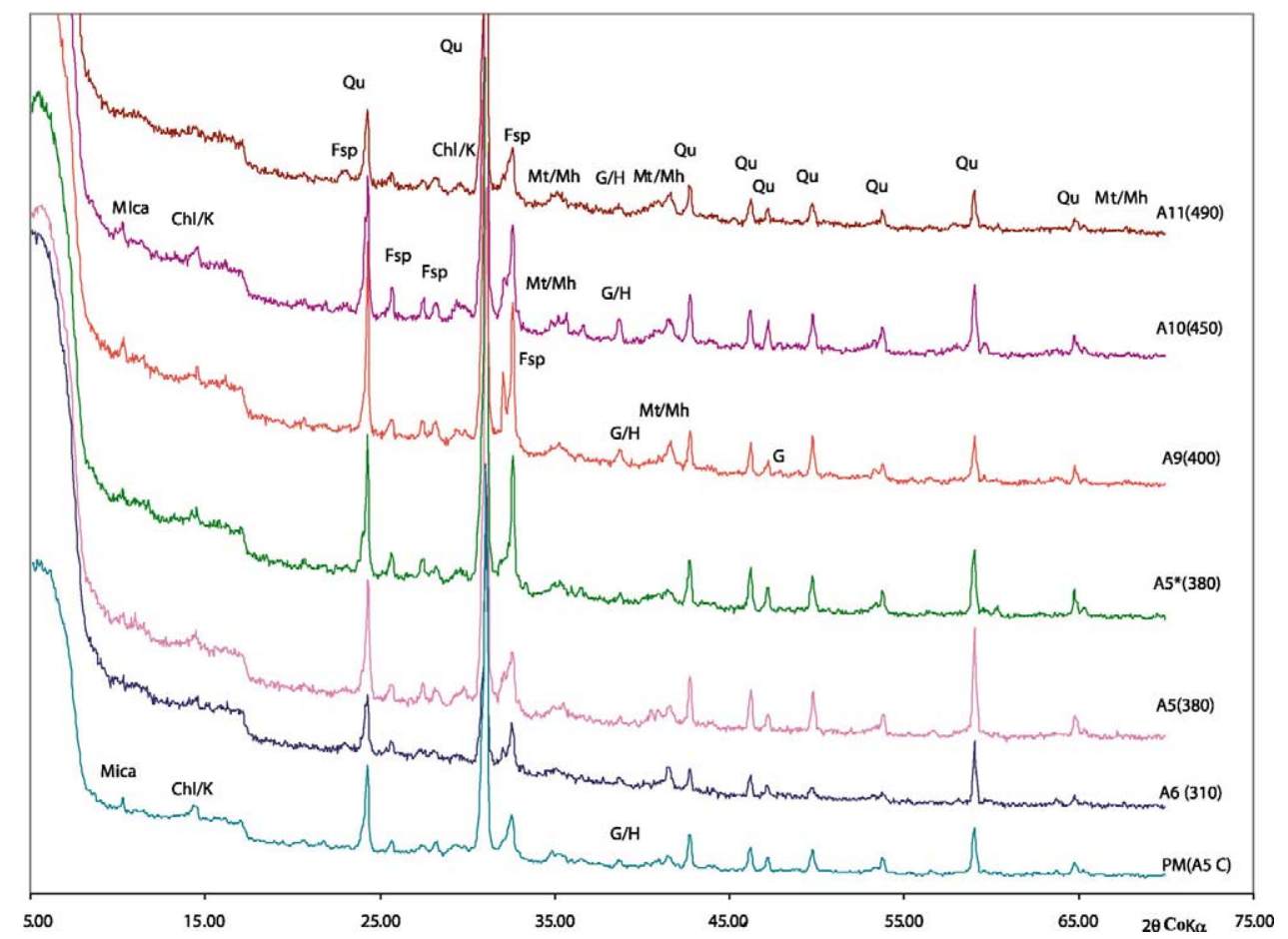

Fig. 9. XRD spectra for MP extracts from the parent material and B horizon samples. Abbreviations: H, haematite; Mt, magnetite; Mh, maghemite; Qu, quartz; Fsp, feldspars; Sm, smectite; Mi, mica; Chl, chlorite; K, kaolinite. 

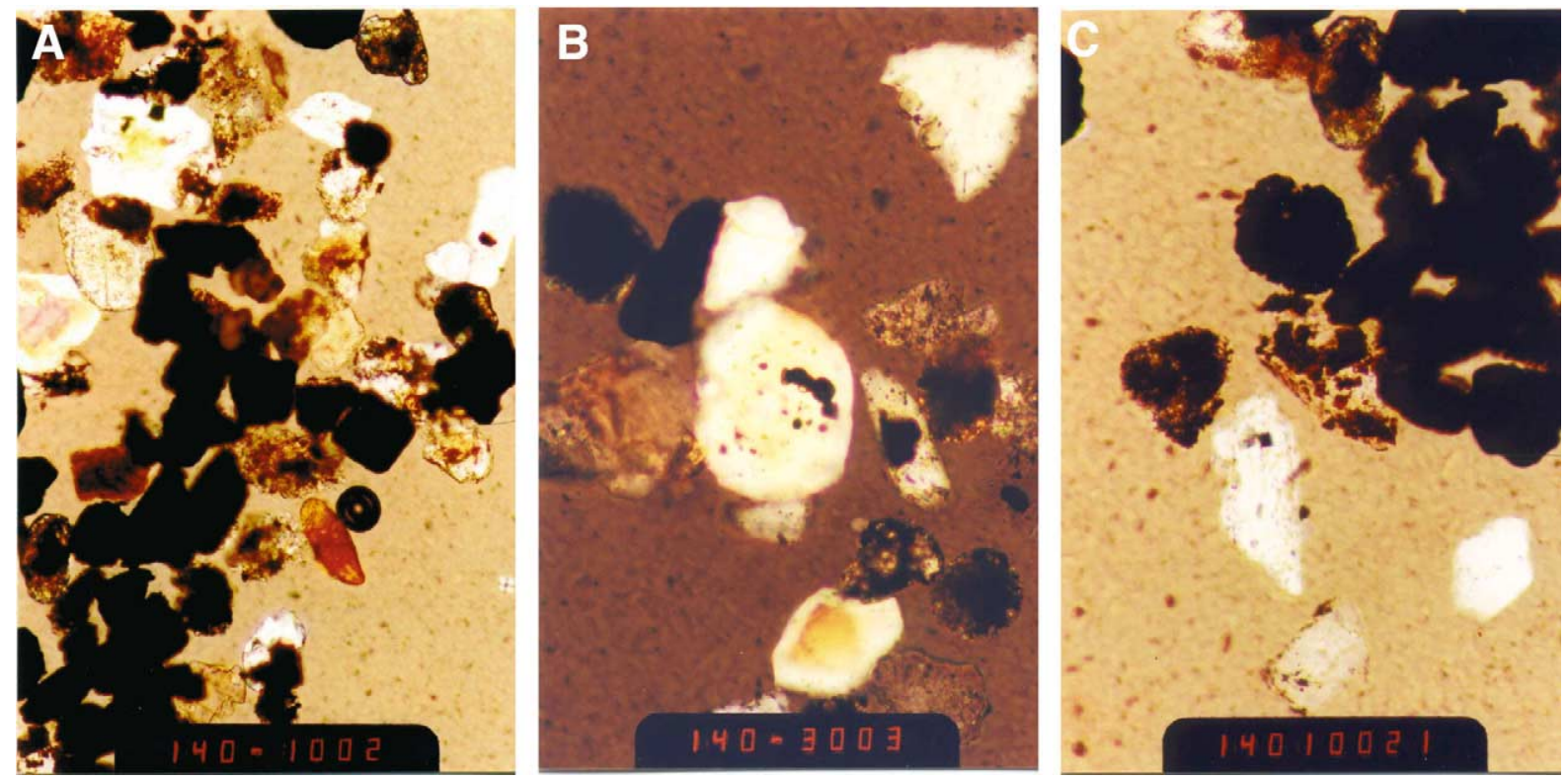

Fig. 10. Optical micrographs for the ME extracts from the B1 horizon of soil profile D451, in transmitted light: (A) view of the extract (magnification $\times 100)$; $(B)$ and $(C)$ opaque inclusions in transparent grains and rock fragments (magnification $\times 200)$.

A99-11, $490 \mathrm{~mm}$ rain p.a.). The haematite/goethite content shows a relative decrease compared with the magnetite content, falling from $40 \%$ in the parent material to $21 \%$ in the most magnetic B horizon. Finally, the $\mathrm{Fe}^{2+}$ content of the parent material can be compared with that of the upper horizons, in order to identify the intensity of silicate weathering during soil formation (Alekseev et al., 1996). Based on this parameter, the weathering intensity also shows a generally increasing trend with increased annual rainfall totals (Table $1)$.

\section{Discussion}

Magnetic and mineralogical analysis of this range of modern, mainly Kastanozem-type soils shows that they contain varying amounts of ultrafine-grained ferrimagnets. The parent substrates of the soils are consistently weakly magnetic but their A and B horizons contain significant additional concentrations of magnetite and maghemite. The pedogenic magnetic content of the soils (e.g. magnetic susceptibility A,B horizon-magnetic susceptibility $\mathrm{C}$ horizon) varies across the sampled transect (Fig. 13). It is at a minimum for the semi-arid zone close to the Caspian Sea (rain $\sim 300 \mathrm{~mm} / \mathrm{yr}$ ) and rises to a maximum for the more humid zone close to the northern Caucasus region $(\sim 500 \mathrm{~mm} / \mathrm{yr})$. Table 3 provides a correlation matrix examining the relationships between the soil transect magnetic properties and the major climate variables. As shown by this matrix, the strongest statistical relationships exist between annual rainfall and $\chi_{\mathrm{LF}}$ and $\chi_{\mathrm{ARM}}$ (correlation coefficients of 0.93), and between summer rainfall and $\chi_{\text {LF }}$ and $\chi_{\text {ARM }}$ (correlation coefficients of 0.85 and 0.84 , respectively). A negative correlation is evident between annual rainfall and HIRM $(-0.68)$.

As established by Dokuchaev (1883) and Jenny (1941), soils, or any particular soil property, reflect the interplay of the five soil-forming factors: parent material, climate, organisms, topography and time. For this region of the Russian steppe, parent materials have uniformly low magnetic concentrations and variability, topography is rolling to flat (only interfluve sites have been sampled) and duration of soil formation apparently constant (there has been minimal accumulation of loess since the last glacial stage). Thus, in terms of soil magnetism, the soil-forming equa- 


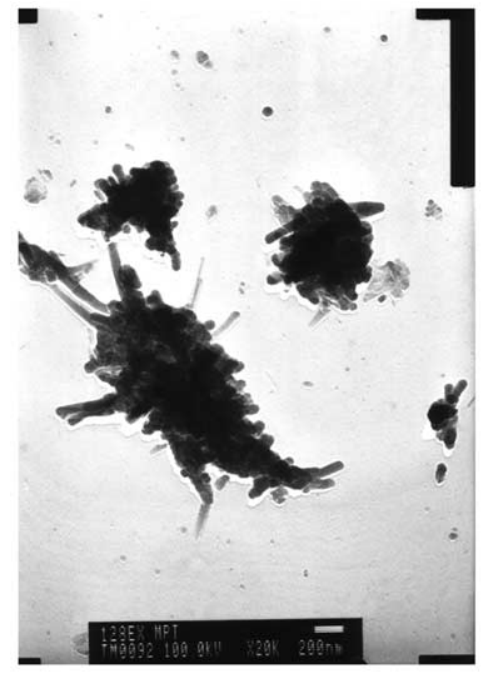

A)

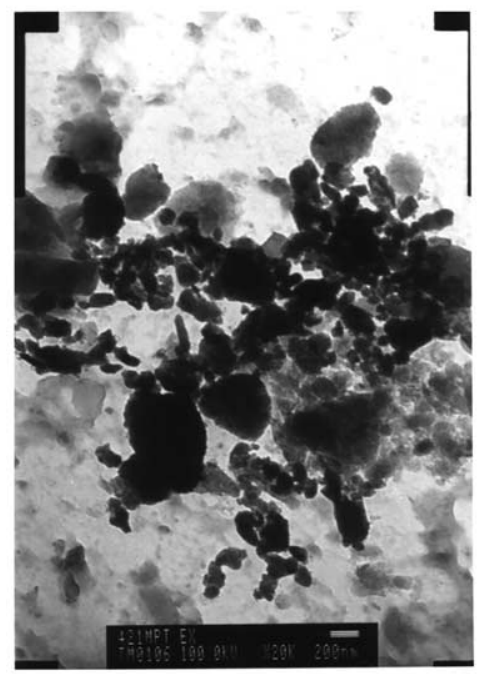

C)

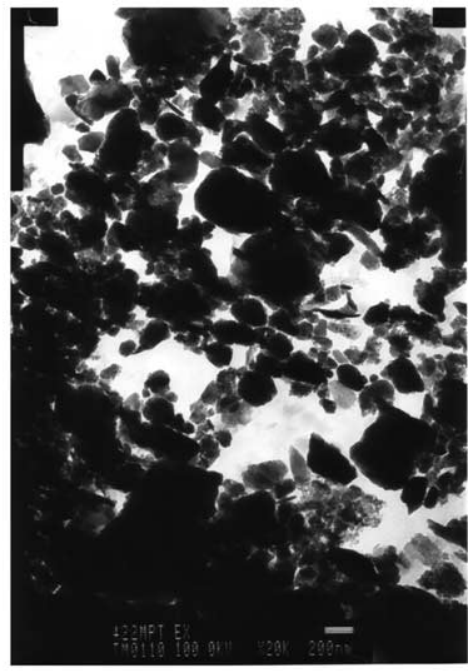

B)

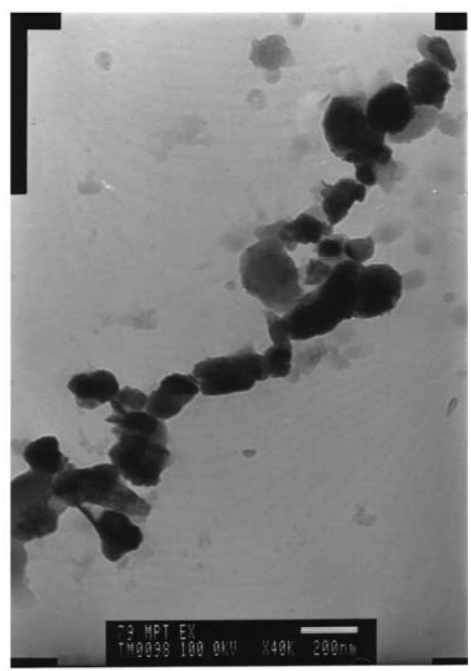

D)

Fig. 11. Transmission electron micrographs for the MP extracts: (A) and (B) from the C horizon samples, (C) and (D) from the B horizon samples. (A) goethite laths $(\sim 500 \mathrm{~nm}$ in length). (B) $>1-\mu \mathrm{m}$ geometric Fe-rich particles of detrital magnetite with occasional ultrafine-grained, geometric, Fe-rich particles $(<\sim 100 \mathrm{~nm})$. (C) Larger, geometric Fe-rich particles $(\sim 200-500 \mathrm{~nm}$ diameter) of detrital magnetite, with additional ultrafine fraction. (D) Ultrafine-grained, geometric, Fe-rich particles $(\sim 10-50 \mathrm{~nm})$ with some (post-extraction?) arrangement in chains.

tion can be reduced in this region to a climofunction (since vegetation will co-vary with climate) that is, the soil magnetic properties vary mostly as a function of climate. Further, the correlation matrix (Table 3) identifies that the major climate variable which influences the soil magnetic properties is annual rainfall. For pedogenic magnetic susceptibility $\left(\chi_{B}-\chi_{C}\right)$, the climofunction for these Russian steppe soils takes the form:

Annual rainfall $=86.4 \operatorname{Ln}\left(\chi_{\mathrm{B}}-\chi_{\mathrm{C}}\right)+90.1$

The new steppe magnetic data can be incorpo- 
A

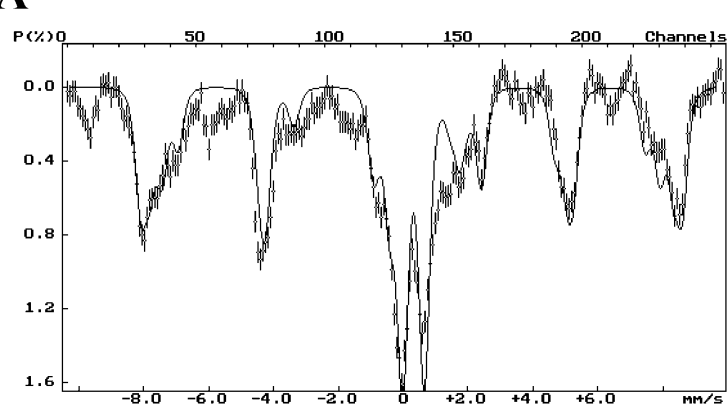

B

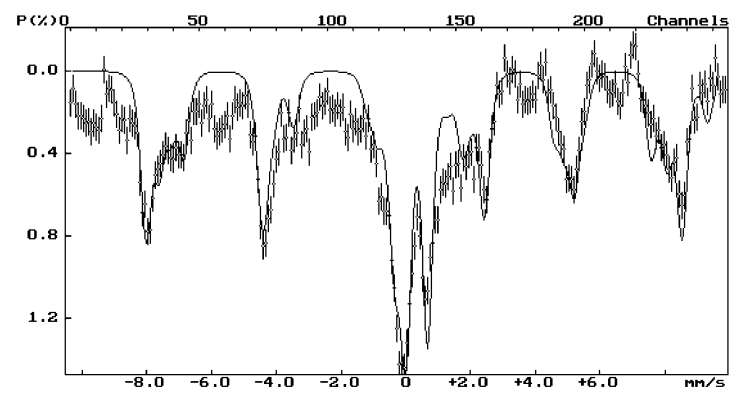

C

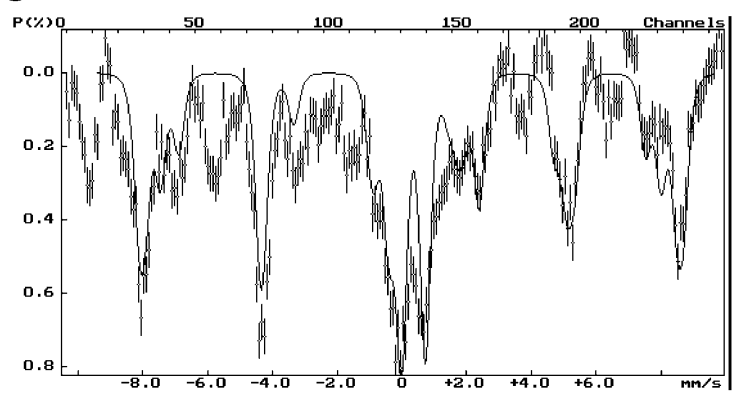

$490 \mathrm{~mm}$

$380 \mathrm{~mm}$

$310 \mathrm{~mm}$

Fig. 12. Room temperature Mössbauer spectra for magnetic extracts from topsoil samples spanning the climate gradient. Note the variation in spectral intensity (y-axis), which increases by $\sim 50 \%$ from spectrum (C) to (A).

rated into Maher and Thompson's (1995) Northern Hemisphere temperate zone dataset. As can be seen from Fig. 13, the magnetic data from the Chinese Loess Plateau and the Russian steppe are highly correlated both with rainfall and with each other. The steppe data thus independently substantiate, and indeed can be used to refine, the previously observed magnetism/rainfall relationship. This high degree of correlation, in two geographically independent regions, identifies the dominance of the rainfall component of the cli- mate system in influencing the pedogenic magnetic properties of these modern soils.

As described previously, soils can take slightly different magnetic enhancement pathways, likely related to other climate variables, such as seasonality (Maher and Thompson, 1999). These Russian soils take a magnetically slightly harder enhancement path compared, for instance, with some of the most enhanced palaeosols from the Chinese Plateau.

Whereas the magnetic susceptibility, $\chi_{\mathrm{ARM}}$ and 
SIRM of these steppe soils are dominated by rather small concentrations of the ferrimagnets, magnetite and maghemite, the high-field remanence $\left(\mathrm{HIRM}_{100 \mathrm{mT} \text { af }}\right)$ is contributed by the weakly magnetic oxide, haematite (the 'saturating' field used here was $1 \mathrm{~T}$, which is insufficient to induce significant remanence from goethite).

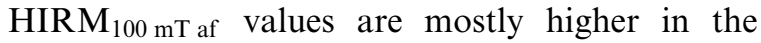
upper soil horizons (compared with the parent loess). HIRM values are also higher in the less magnetic soils, at the more arid end of the sampled transect. These increases in HIRM indicate formation of haematite, as well as ferrimagnets, during soil development, especially in the more arid soils. The HIRM values indicate haematite concentrations of between $\sim 0.08$ and $4 \%$ (compared with magnetite/maghemite concentrations of $0.04-0.2 \%$ ). These magnetic data match well with the Mössbauer analysis, which also indicate decreasing amounts of haematite/ goethite in the wetter, more magnetic soil profiles.

In laboratory experiments, any of the iron oxide and hydroxide species can be formed in conditions realistic in terms of soil environments (i.e. at room temperature and pressure, and near-neutral $\mathrm{pH}$ ), via oxidation of $\mathrm{Fe}^{2+} / \mathrm{Fe}^{3+}$ suspensions. Fig. 14 (adapted from Schwertmann and Taylor, 1987) identifies possible pathways of oxide formation, and the environmental factors which favour formation of any particular oxide. Higher oxidation rates, higher organic matter and lower $\mathrm{pH}$ ( 4-6) favour formation of goethite (Taylor et al., 1987), whilst haematite is favoured by higher temperatures, decreased water activity and higher $\mathrm{pH}$ ( 7-8) (Schwertmann and Taylor, 1987; Schwertmann, 1988). In soils, magnetite formation requires the initial presence of some $\mathrm{Fe}^{2+}$ cations. Even in generally well-drained and oxic soils, like the loessic soils here, $\mathrm{Fe}^{2+}$ can be

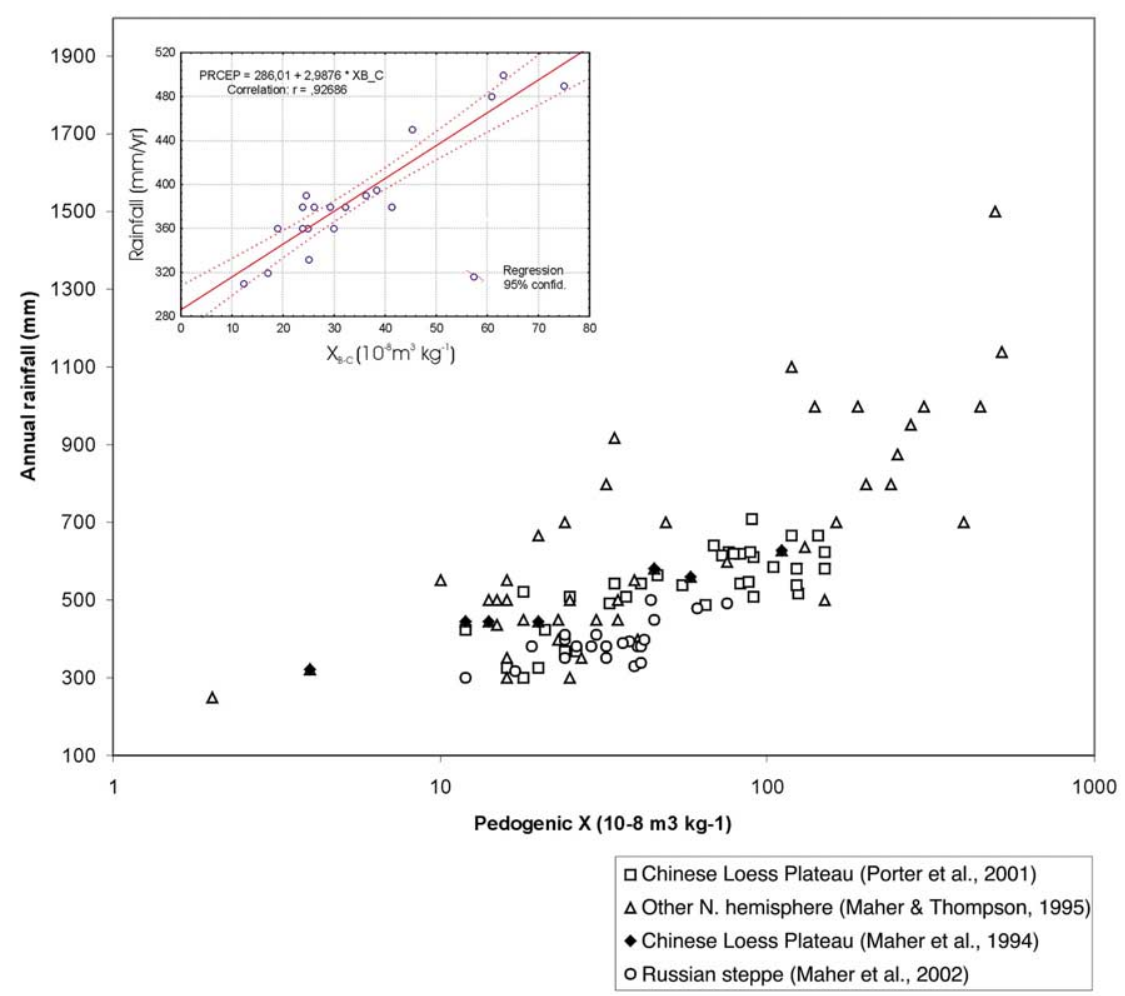

Fig. 13. Pedogenic magnetic susceptibility vs. annual rainfall across the sampled steppe transect (inset) and included within the Northern Hemisphere dataset. Whilst correlation exists between rainfall and several different magnetic parameters, a multi-parameter proxy approach performs no better statistically than that based on magnetic susceptibility alone. 


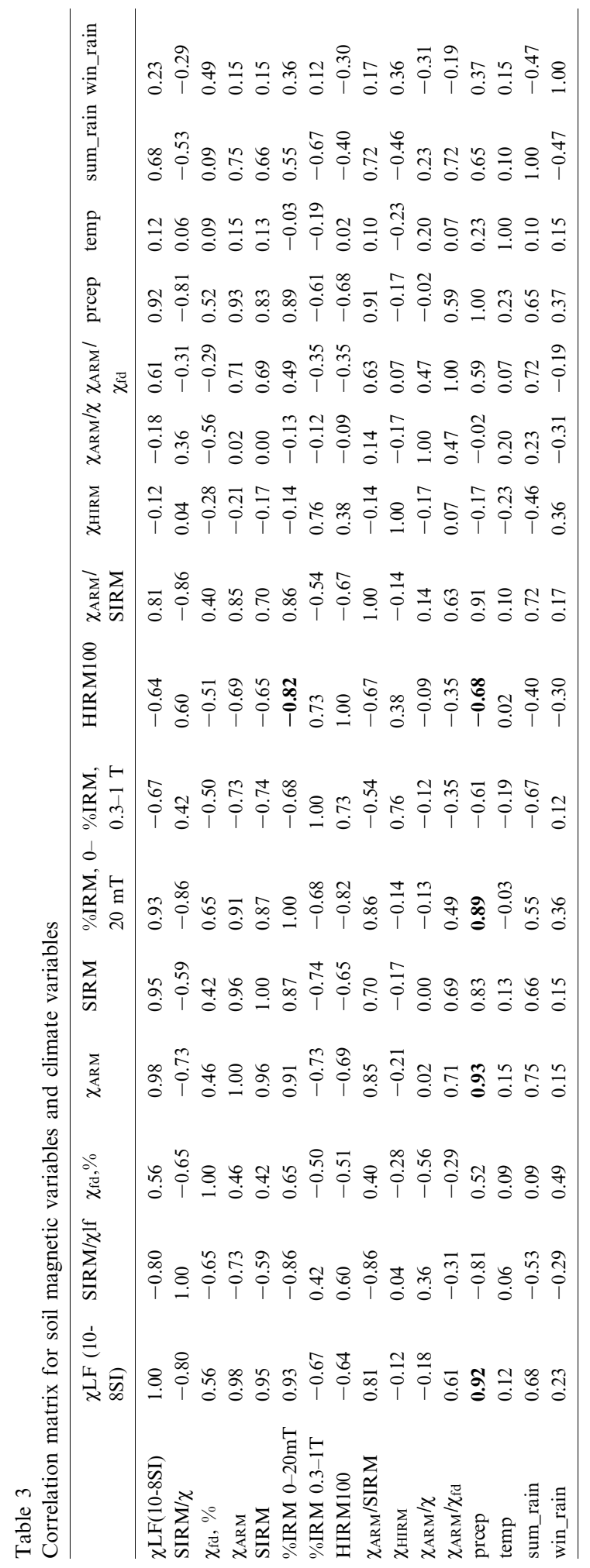

formed in soil micro-zones, made temporarily anoxic during periods of soil wetness, via the activity of iron-reducing bacteria (Starkey and Halvorson, 1927; Munch and Ottow, 1980; Lovley et al., 1987; Rossello-Mora et al., 1995). In this model of pedogenic magnetite formation, intermittent wetting and drying of soils will thus favour formation of magnetite (with bacterial mediation), in the presence of organic matter and a weathering source of iron. This relationship between soil wetting and drying and formation of magnetite may account for the strong, and therefore possibly causal, correlation between pedogenic magnetite and rainfall. Because the action of each iron-reducing bacterium can mediate the formation of hundreds of ferrimagnetic grains, this pathway can account for the magnetic concentrations observed in the steppe and loess soils. Further biological/climatic coupling may arise from vegetation/iron mineral interactions. Correlation has been observed between soil magnetic concentrations (as measured by susceptibility or saturation remanence) and organic carbon (Maher, 1998). Plants can transport iron from deeper soil layers to the surface via leaf litter fall; it is also possible that magnetite, as the inorganic core of plant phytoferritin, may constitute a more direct (but so far unquantified) source of soil ferrimagnets, of ultrafine $(1-50 \mathrm{~nm})$ grain size (McClean et al., 2001). Evans and Heller (1994) have noted that the magnetic grain size distributions of the palaeosols spanning the Chinese Loess Plateau appear very similar (as indicated by their magnetic coercivity spectra). On this basis, they suggest that magnetotactic bacteria are responsible for pedogenic magnetite formation in these soils. However, these bacteria produce ferrimagnetic crystals within biologically-constrained membranes within their cells and so the ferrimagnets tend to have a narrow grain size spread and thus a narrow coercivity spectrum. Such magnetic behaviour is in contrast with the observation that coercivity spectra tend to broaden, rather than constrict, with increasing degree of soil development (e.g. Fig. 7). While the grain size of the bacterial magnetite could subsequently be altered during soil formation, due to processes of dissolution, it also seems unlikely that such dissolution would operate to similar de- 


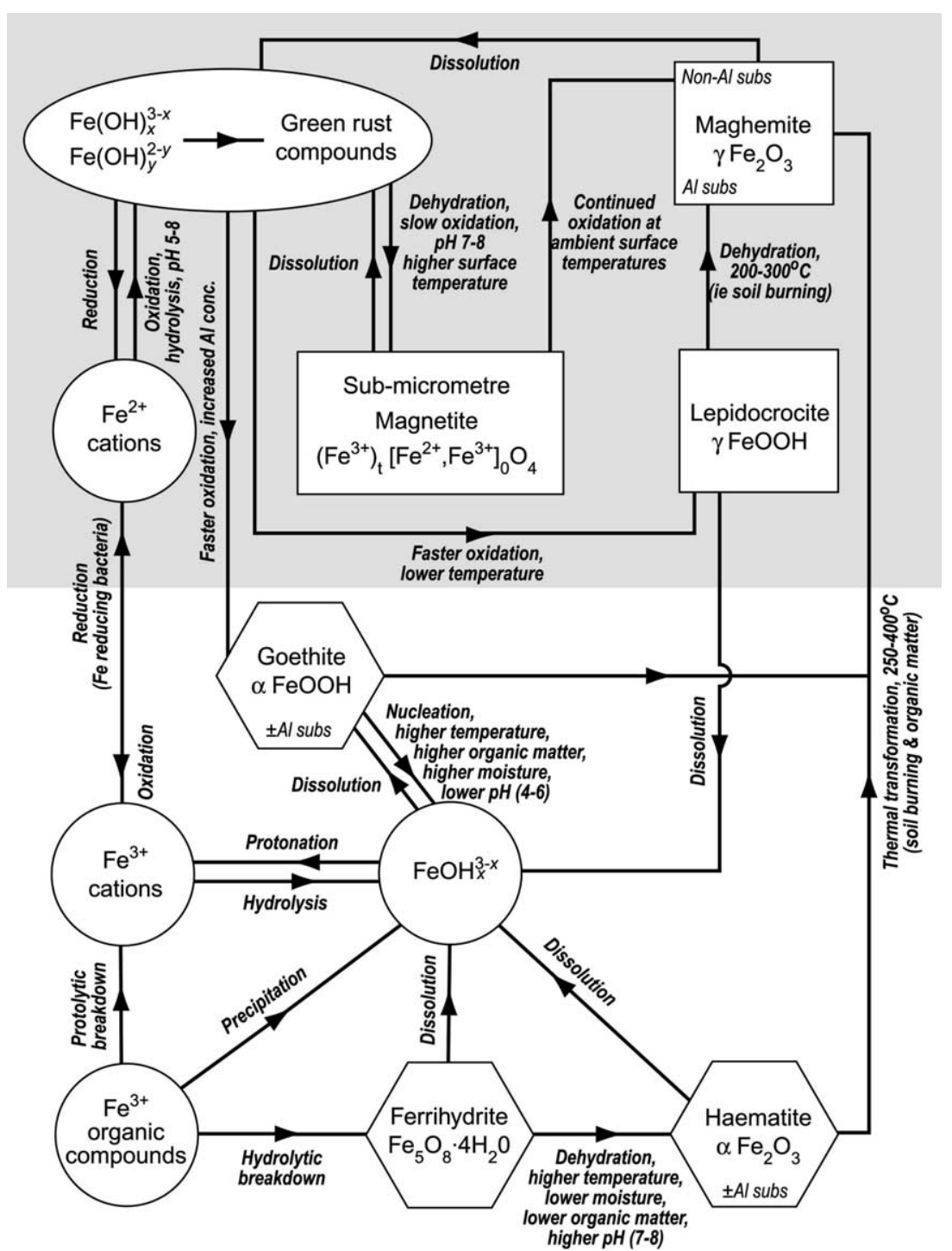

Fig. 14. Pathways of iron oxide formation in pedogenic environments (adapted from Schwertmann and Taylor, 1987). Iron-reducing bacteria are likely to be involved at many of the reduction/dissolution steps (also see Fig. 15).

grees at sites across the Loess Plateau to produce the observed similarity of grain size distribution. An alternative explanation relates to the action of the Fe-reducing bacteria, which may provide the initial source of $\mathrm{Fe}^{2+}$ cations required for magnetite formation (Fig. 14). Laboratory syntheses of magnetite (Taylor et al., 1987) show that the size to which synthetic crystals grow is controlled particularly by oxidation rate, $\mathrm{pH}$, and $\mathrm{Fe}$ concentration. To produce a 'constant' grain size distribu- tion (as in the soils across the Plateau), magnetite formation must thus be initiated under 'constant' environmental conditions. Such constancy in the natural environment can be explained if the bacteria which produce the required $\mathrm{Fe}^{2+}$ (e.g. Shewanella sp.; Geobacter sp.) only operate within, and/or create via their metabolism (Bell et al., 1987), a certain set of $\mathrm{pH}, \mathrm{Eh}$ and $\mathrm{Fe}$ conditions (Fig. 15). In the laboratory experiments by Taylor et al. (1987) the magnetite grain size distribution 


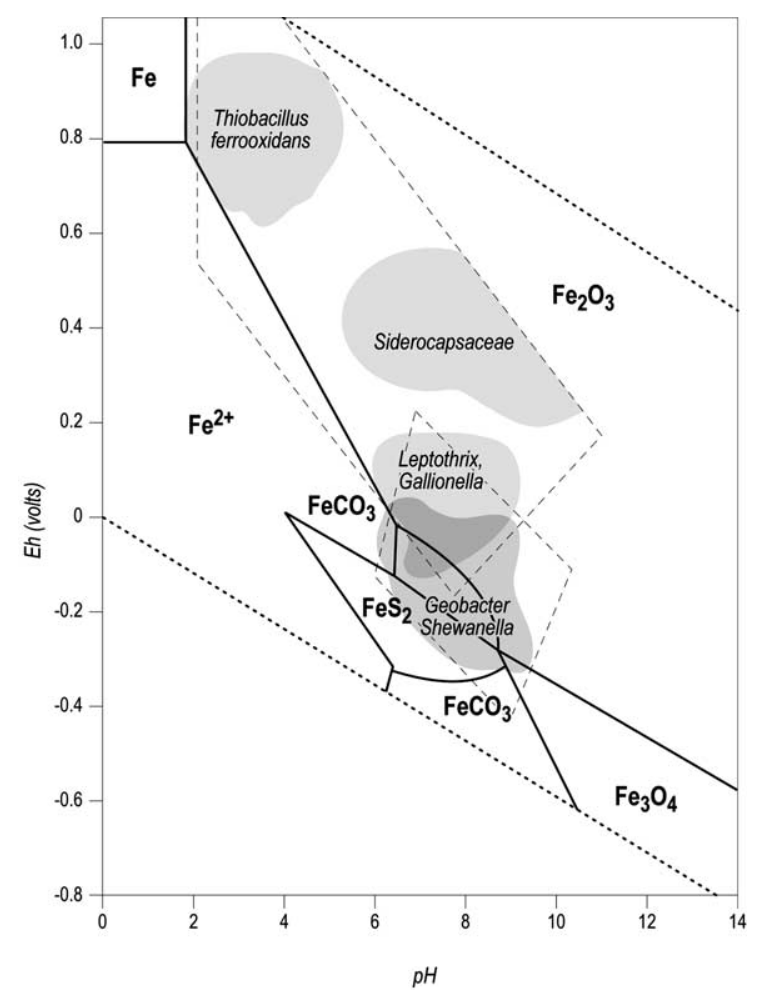

Fig. 15. Eh-pH stability fields for iron compounds, together with preferred redox/pH ranges for the major groups of iron-oxidising (eg. Thiobacillus f., Leptothrix, Gallionella) and iron-reducing bacteria (Shewanella, Geobacter). After Zavarzina, 2001.

typical of the Chinese soils is produced with a $\mathrm{pH}$ of 7.5 , at $26^{\circ} \mathrm{C}$ and an oxidation rate of $4 \mathrm{ml}$ air/ $\min$.

In contrast to these optimal magnetite-forming conditions, longer periods of dryness, with increased oxidation rates and reduced water activity, would favour formation of the more oxic iron compounds, haematite and goethite (Maher, 1998; Ji et al., 2001). In arid environments, therefore, little formation of pedogenic ferrimagnets would be predicted, and thus pedogenic susceptibility would show little sensitivity to climate (Thompson and Maher, 1995). Similarly, in areas of excessively high rainfall ( $>\sim 2000 \mathrm{~mm} / \mathrm{yr}$ ), with resultant decalcification and thus decreased buffering capacity, pedogenic magnetite again may not form or may be subjected to dissolution, and the rainfall/susceptibility climofunction would break down (Maher, 1998; Guo et al., 2001).
Thus, within a certain rainfall range (e.g. Fig. 1), a climatically determined equilibrium magnetic value may be reached due to feedback between formation of ferrimagnets and their subsequent loss by oxidation or dissolution (Maher, 1998; Maher et al., 2002).

\section{Conclusions}

(1) The concentration of SP- and SD-sized ferrimagnets is greater in the $\mathrm{A}$ and $\mathrm{B}$ horizons of the Kastanozem-type soils spanning the Russian loessic steppe, compared with their rather homogenous and weakly magnetic parent substrates. Magnetic susceptibility, frequency dependent susceptibility and $\chi_{\mathrm{ARM}} / \mathrm{SIRM}$ ratios of the topsoils all increase systematically from the arid margins of the Caspian Sea to the more humid fringes of the Caucasus Mountains. The magnetic measurements indicate that concentrations of magnetite/ maghemite vary from $\sim 0.04 \%$ in the parent materials to a maximum of $\sim 0.2 \%$ in the wettest part of the transect, in the A and B horizons.

(2) Mössbauer analysis of magnetic extracts from representative $\mathrm{A}, \mathrm{B}$ and $\mathrm{C}$ horizon samples confirm independently the increases in magnetite/ maghemite concentrations in the upper soil horizons. From the Mössbauer spectra, analysis of the $\mathrm{Fe}^{2+}$ contents of the parent material and the A and $\mathrm{B}$ horizons indicates that pedogenic formation of ferrimagnets accompanies the weathering of detrital Fe-silicates. Electron microscopy identifies that much of the new, pedogenic magnetic material occurs as reasonably crystalline, pure (Fe-rich), ultrafine grains $(<\sim 50 \mathrm{~nm})$.

(3) The soils in the semi-arid parts of the transect also form haematite during their development, as indicated by their higher HIRM $100 \mathrm{mT}$ af values, compared with the parent loess. However, the amount of haematite formed decreases with increasing annual rainfall.

(4) Given that parent material, time and topography are effectively constant across the sampled transect, the observed spatial variations in soil magnetic properties dominantly reflect iron oxide transformations influenced by climate (and its covariant, organic activity). From statistical analy- 
sis, the most significant correlation is between annual rainfall and both magnetic susceptibility and $\chi_{\text {ARM }}(r=0.93)$.

(5) The magnetic mineralogy of these steppe soils appears to reflect present-day rainfall variations across this geographic and climatic transect. These soils are subject to neither loess accumulation nor industrial pollution at the present day.

(6) The pedogenic magnetic response of these well-drained, near-neutral, Russian steppe soils appears strongly correlated with that of the similarly well-drained and buffered modern soils across the Chinese Loess Plateau (and across the wider Northern Hemisphere temperate zone). Such correlation suggests that the rainfall component of the climate system is a key influence on soil magnetic properties in both these regions. This direct coupling of the soil magnetism of modern soils with present-day climate substantiates the use of magnetic climofunctions to make quantitative estimates of past rainfall variations from the magnetic properties of buried palaeosols for both the Russian steppe and the Chinese Loess Plateau. However, as noted previously, the climofunction will be insensitive to climate in such arid environments $(<\sim 100 \mathrm{~mm} / \mathrm{yr}$ rain $)$ that pedogenic ferrimagnets do not form, or in highly humid environments ( $>\sim 2000 \mathrm{~mm} / \mathrm{yr}$ rain) where gleying and/or increased soil acidity may cause dissolution of pedogenic magnetite.

\section{Acknowledgements}

We are very grateful for the financial support from the NATO Science Programme and the Russian Foundation for Basic Research, which enabled this project to be carried out.

Appendix A. Methods and instruments

\section{A.1. Magnetic measurements}

Each sample was dried and packed into 10-cc plastic cylinders. Magnetic susceptibility was mea- sured at low $(0.46 \mathrm{kHz})$ and high $(4.6 \mathrm{kHz})$ frequencies, using a Bartington Instruments MS2 susceptibility meter. ARMs were imparted in an alternating field of $80 \mathrm{mT}$ with a biasing DC field of $0.08 \mathrm{mT}$ (Molspin AF demagnetiser, with dc attachment). The susceptibility of ARM $\left(\chi_{\text {ARM }}\right)$ is calculated by normalising the ARM by the intensity of the applied bias field. IRMs were imparted, after demagnetisation of ARMs, in pulsed fields of 10, 20, 50, 100 and $300 \mathrm{mT}$ (Molspin pulse magnetiser) and a DC field of $1000 \mathrm{mT}$ (Newport 4" Electromagnet). HIRMs were AF demagnetised at $100 \mathrm{mT}$. All magnetic remanences were measured using a fluxgate magnetometer (Molspin Ltd., sensitivity $\sim 10^{-7} \mathrm{~A} \mathrm{~m}^{2}$ ). Magnetic hysteresis was measured using a Molspin VSM Nuvo.

\section{A.2. Magnetic extractions}

Prior to magnetic extraction, the samples were decalcified using buffered acetic acid and were then particle-sized into $<38-\mu \mathrm{m}$ and $>38-\mu \mathrm{m}$ fractions. Mineral grains were extracted using the magnetised probe method and the magnetic edge method (Hounslow and Maher, 1999). The amount of magnetic material extracted at each stage was quantified by before- and after-extraction magnetic measurements (susceptibility, ARM).

\section{A.3. XRD}

The major and minor mineral phases in the magnetic separates were identified by XRD, using a Philips PW1710 X-ray diffractometer with monochromatic $\mathrm{Cu}$ and Co-radiation, automatic divergence slit and scan speed $0.005^{\circ} 2 \theta \mathrm{s}^{-1}$. The estimates of the mineral abundances were based on subsequent peak intensities.

\section{A.4. Mössbauer analysis}

Mössbauer spectra were obtained with a MS1101E spectrometer with a constant acceleration drive system $\left({ }^{57} \mathrm{Co} / \mathrm{Cr}\right.$ source with an activity 
of about $64 \mathrm{mCi}$ ). The velocity scale was calibrated relative to $\mathrm{Fe}$ and sodium nitroprusside. The relative content of total and divalent iron, as well the proportions of magnetite (maghemite) and goethite, in the magnetic extracts were established from numerical analyses. The room-temperature spectra for the magnetic extracts were fitted with two magnetite sextets, one maghemite sextet and one haematite sextet, and doublets of $\mathrm{Fe}^{3+}$ and $\mathrm{Fe}^{2+}$.

\section{A.5. Microscopy}

Optical microscopy of polished sections made from $>38-\mu \mathrm{m}$ magnetic particles was used to provide information on the grain size, their morphology and composition. It also enabled identification of the presence and significance of ferrimagnetic inclusions within various silicate minerals. For examination of the ultrafine magnetic separates, transmission electron microscopy (JEOL JEM-2000EX), with energy dispersive X-ray analysis (Link Systems Ltd.) was used.

\section{References}

Alekseev, A.O., Alekseeva, T.V., Maher, B.A., in press. Magnetic properties and mineralogy of iron compounds in steppe soils. Pochvovedenie N1.

Alekseev, A.O., Alekseeva, T.V., Morgun, E.G., Samoylova, E.M., 1996. Geochemical regularities of iron state in soils of conjugate landscapes of Central Precaucasus. Litologiya i poleznue iskopaemue $\mathrm{N} \mathrm{1,} \mathrm{12-22.}$

Babanin, V.F., 1973. The use of magnetic susceptibility in identifying forms of iron in soils. Sov. Soil Sci. 5, 487-493.

Bean, C.P., Livingston, J.D., 1959. Superparamagnetism. J. Appl. Phys. 30, 120S-129S.

Bell, P.E., Mills, A.L., Herman, J.S., 1987. Biogeochemical conditions favouring magnetite formation during anaerobic iron reduction. Appl. Env. Microbiol. 53, 2610-2616.

Dankers, P.H.M., 1978. Magnetic Properties of Dispersed Natural Iron Oxides of Known Grain Size. Ph.D. Thesis, University of Utrecht.

Dearing, J.A., Dann, R.J.L., Lees, J.A., Loveland, P.J., Maher, B.A., O'Grady, K., 1996. Frequency dependent susceptibility measurements of environmental materials. Geophys. J. Int. 124, 228-240.

Dokuchaev, V.V., 1883. Russian Chernozem. St. Petersburg.

Dunlop, D.J., 1981. The rock magnetism of fine particles. Phys. Earth Planet. Int. 26, 1-26.
Evans, M.E., Heller, F., 1994. Magnetic enhancement and paleoclimate: Study of a loess/palaeosol couplet across the Loess Plateau. Geophys. J. Int. 117, 257-264.

Guo, B., Zhu, R.X., Roberts, A.P., Florindo, F., 2001. Lack of correlation between paleoprecipitation and magnetic susceptibility of Chinese loess/paleosol sequences. Geophys. Res. Lett. 28, 4259-4262.

Han, J., Lu, H., Wu, N., Guo, Z., 1996. Magnetic susceptibility of modern soils in China and climate conditions. Stud. Geophys. Geodet. 40, 262-275.

Heller, F., Shen, C.D., Beer, J., Liu, X.M., Liu, T.S., Bronger, A., Suter, M., Bonani, G., 1993. Quantitative estimates and paleoclimatic implications of pedogenic ferromagnetic mineral formation in Chinese loess. Earth Planet. Sci. Lett. 114, 385-390.

Hounslow, M.W., Maher, B.A., 1996. Quantitative extraction and analysis of carriers of magnetisation in sediments. Geophys. J. Int. 124, 57-74.

Hounslow, M.W., Maher, B.A., 1999. Laboratory procedures for quantitative extraction and analysis of magnetic minerals from sediments. In: Walden, J. Oldfield, F., Smith, J.P. (Eds), Environmental Magnetism: A Practical Guide. Quaternary Research Association, Cambridge, pp. 139-184.

Jenny, H., 1941. Factors of Soil Formation. McGraw-Hill.

Ji, J., Balsam, W., Chen, J., 2001. Mineralogic and climatic interpretations of the Luochuan loess section (China) based on diffuse reflectance spectrophotometry. Quat. Res. 56, 2330.

Kukla, G., Heller, F., Liu, X.M., Xu, T.C., Liu, T.S., An, Z.A., 1988. Pleistocene climates in China dated by magnetic susceptibility. Geol. 16, 811-814.

Liu, X.M., Rolph, T., Bloemendal, J., Shaw, J., Liu, T.S., 1995. Quantitative estimates of paleoprecipitation at Xifeng, in the Loess Plateau of China. Palaeogeogr. Palaeoclimatol. Palaeoecol. 113, 243-248.

Lovley, D.R., Stolz, J.F., Nord, G.L., Phillips, E.J.P., 1987. Anaerobic production of magnetite by a dissimilatory ironreducing microorganism. Nature 330, 252-254.

McClean, R.G., Schofield, M.A., Kean, W.F., Sommer, C.V., Robertson, D.P., Toth, D., Gajdardziska-Josifovska, M., 2001. Botanical iron minerals: Correlation between nanocrystal structure and modes of biological self-assembly. Eur. J. Mineral. 13, 1235-1242.

Maher, B.A., Alekseev, A., Alekseeva, T., 2002. Variation of soil magnetism across the Russian steppe: Its significance for use of soil magnetism as a paleorainfall proxy. Quat. Sci. Rev. 21, 1571-1576.

Maher, B.A., Thompson, R., 1999. Paleomonsoons, I. The paleoclimatic record of the Chinese loess and palaeosols. In: Maher, B.A., Thompson, R. (Eds.), Quaternary Climates, Environments and Magnetism. Cambridge University Press, pp. 81-125.

Maher, B.A., Thompson, R., Hounslow, M.W., 1999. Introduction to Quaternary climates, environments and magnetism. In: Maher, B.A., Thompson, R. (Eds.), Quaternary Climates, Environments and Magnetism. Cambridge University Press, pp. 1-48. 
Maher, B.A., 1998. Magnetic properties of modern soils and loessic palaeosols: Implications for palaeoclimate. Palaeogeogr. Palaeoclimatol. Palaeoecol. 137, 25-54.

Maher, B.A., Thompson, R., 1995. Paleorainfall reconstructions from pedogenic magnetic susceptibility variations in the Chinese loess and paleosols. Quat. Res. 44, 383-391.

Maher, B.A., Thompson, R., Zhou, L.P., 1994. Spatial and temporal reconstructions of changes in the Asian paleomonsoon: A new mineral magnetic approach. Earth Planet. Sci. Lett. 125, 461-471.

Maher, B.A., 1988. Magnetic properties of some synthetic submicron magnetites. Geophys. J. 94, 83-96.

Maher, B.A., 1986. Characterization of soils by mineral magnetic measurements. Phys. Earth Planet. Int. 42, 76-92.

Munch, J.C., Ottow, J.C.G., 1980. Preferential reduction of amorphous to crystalline iron oxides by bacterial activity. Soil Sci. 129, 15.

Özdemir, Ö., Banerjee, S.K., 1982. A preliminary magnetic study of soil samples from west-central Minnesota. Earth Planet. Sci. Lett. 59, 393-403.

Petersen, N., von Dobeneck, T., Vali, H., 1986. Fossil bacterial magnetite in deep-sea sediments from the South Atlantic Ocean. Nature 320, 611-615.

Porter, S.C., Hallet, B., Wu, X, An, Z., 2001. Dependence of near-surface magnetic susceptibility on dust accumulation rate and precipitation on the Chinese Loess Plateau. Quat. Res. 55, 271-283.

Rossello-Mora, R.A., Caccavo, F., Osterlegner, K., Springer, N., Spring, S., Schuler, D., Ludwig, W., Amann, R., Vanncanneyt, M., Schleifer, K.H., 1995. Isolation and taxonomic characterization of a halotolerant, facultatively iron-reducing bacterium. Syst. Appl. Microbiol. 17, 569-573.

Schwertmann, U., 1988. Occurrence and formation of iron oxides in various pedoenvironments. In: Stucki, J.W., Goodman, B.A., Schwertmann, U. (Eds.), Iron in Soils and Clay Minerals. NATO ASI Series C217, Reidel, Dordrecht, pp. 267-308.
Schwertmann, U., Taylor, R.M., 1987. Iron oxides. In: Dixon, J.B., Weed, S.B. (Eds.), Minerals in Soil Environments, 2nd ed. Soil Sci. Soc. Am., Madison.

State Meteorological Organisation, 1966. Handbook on the Climate of USSR 13, part 2. Hydrometeorological Publishing House, Leningrad.

State Meteorological Organisation, 1968. Handbook on the Climate of USSR 13, part 4. Hydrometeorological Publishing House, Leningrad.

Starkey, H.L., Halvorson, H.O., 1927. Studies on the transformation of iron in nature, II. Concerning the importance of micro-organisms in the solution and precipitation of iron. Soil Sci. 14, 381-402.

Taylor, R.M., Maher, B.A., Self, P.G., 1987. Magnetite in soils, I. The synthesis of single-domain and superparamagnetic magnetite. Clay Miner. 22, 411-422.

Thompson, R., Maher, B.A., 1995. Age models, sediment fluxes and palaeoclimatic reconstructions for the Chinese loess and palaeosol sequences. Geophys. J. Int. 123, 611622.

Vadyunina, A.F., Smirnov, Yu.A., 1976. Natural remanent magnetisation of some soils. Sov. Soil Sci. 8, 471.

Vali, H., Förster, O., Amarantidis, G., Petersen, N., 1987. Magnetotactic bacteria and their magnetofossils in sediments. Earth Planet. Sci. Lett. 86, 389-400.

Vodyunitsky, Y.N., 1981. Formation of ferromagnetics in sodpodsolic soil. Pochvovedeniye 5, 114-122.

von Dobeneck, T., 1985. Gesteinsmagnetische Untersuchungen an Tiefseesedimenten des Sudatlantiks. Diplomarbeit Inst. Allg. Angew. Geophys., Ludw.-Max. Univ., München.

von Dobeneck, T., 1996. A systematic study of natural magnetic mineral assemblages based on modelling hysteresis loops with coercivity-related hyperbolic basis functions. Geophys. J. Int., 124, 675-694

Zavarzina, D.G., 2001. Biogeochemical Factors of Iron Compounds Transformation in Redox Conditions. Ph.D. Thesis, Moscow State University. 